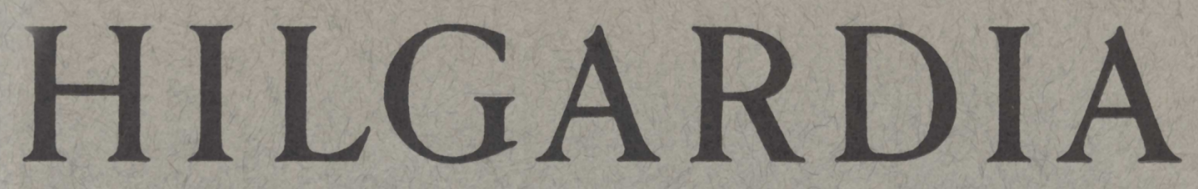

A Journal of Agricultural Science Published by the California Agricultural Experiment Station

\begin{tabular}{lll}
\hline VOLUME 21 & FEBRUARY, 1952 & NUMBER 9 \\
\hline
\end{tabular}

\title{
A GUIDE TO THE SPIDER MITES OF DECIDUOUS FRUIT TREES
}

A. EARL PRITCHARD and EDWARD W. BAKER

UNIVERSITY OF CALIFORNIA - BERKELEY, CALIFORNIA 
The recent development of highly selective acaricides for spider mite control has made it necessary for the economic entomologist to know the particular species he is dealing with. This report, a guide to the spider mites known to occur on deciduous fruit trees in the United States and Canada, is intended to aid him in making determinations in the field and in the laboratory. Included are a taxonomic key to the species, a field guide, and instructions for sampling, slide preparation, and recognition of diagnostic characters. Of special interest are three new combinations, one new species, four new synonyms, and new information on color forms and seasonal phases of Tetranychus bimaculatus.

The following twelve species of spider mites are treated:

Bryobia praetiosa Koch (p. 259)

Metatetranychus ulmi (Koch) (p. 260)

Paratetranychus newcomeri McGregor (p. 261)

Eotetranychus carpini borealis (Ewing), new combination (p. 261)

Eotetranychus willamettei (McGregor), new combination (p. 263)

Eotetranychus uncatus Garman, new species (p. 263)

Tetranychus pacificus McGregor (p. 265)

Tetranychus mcdanieli McGregor (p. 266)

Tetranychus scboenei McGregor (p. 266)

Tetranychus canadensis (McGregor), new combination (p. 267)

Tetranychus bimaculatus Harvey (p. 268)

Tetranychus atlanticus McGregor (p. 271) 


\section{H I L G A R D I A}

A Journal of Agricultural Science Published by

the California Agricultural Experiment Station

VoL. 21

FEBRUARY, 1952

No. 9

\section{A GUIDE TO THE SPIDER MITES OF DECIDUOUS FRUIT TREES ${ }^{1}$}

\section{A. EARL PRITCHARD ${ }^{2}$ and EDWARD W. BAKER ${ }^{3}$}

\section{INTRODUCTION}

DURING THE PAST DECADE, spider mites have become of increasing importance as pests of deciduous fruit trees in North America. The newer acaricides being developed for spider mite control are often highly selective in their action (see Borden and Madsen, $1951^{4}$ ), making it imperative for the economic entomologist to know the particular species with which he is concerned. The present guide is intended to aid him in making determinations.

Twelve species of spider mites are known to occur on deciduous fruit trees in the United States and Canada. Within a given area one may encounter only one or two species, but as many as eight have been found on fruit trees in the Yakima Valley, Washington.

Different species may be found in near-by orchards, and different species may predominate as the season advances. Often there is a marked change in the prevalence of various species from season to season. Repeated identification of spider mites is thus necessary in considering selection of acaricides for their control.

Bryobia praetiosa Koch and Metatetranychus ulmi (Koch) may be readily and accurately determined in the field. Species belonging to the genera Tetranychus and Eotetranychus, however, are accurately determined only with slide preparations, and samples of these mites must be taken periodically for examination in the laboratory.

Identification of the species involved is seldom difficult for an entomologist who is working with an agricultural crop that is known to be infested with a small number of species. He should be able to make determinations similar to those of the taxonomic specialist if he knows the characters that may be used for identifying the particular species with which he is concerned.

\footnotetext{
${ }^{1}$ Received for publication November 29, 1951.

${ }^{2}$ Assistant Professor of Entomology and Assistant Entomologist in the Experiment Station, Berkeley.

${ }^{3}$ U. S. Department of Agriculture, Agricultural Research Administration, Bureau of Entomology and Plant Quarantine.

"See "Literature Cited" (p. 272) for citations, referred to in the text by author and date.
} 
However, it should be recognized that there are many difficulties involved in the taxonomy of the spider mites of deciduous fruits. This guide is merely a progress report on their classification, as is any taxonomic paper.

There are a number of factors that complicate their classification. Many of the economic species are biologically in a state of flux, and it is often difficult to determine the limits of variation. Man has altered their distribution by transporting them to new agricultural areas, and he has affected their populations with the widespread use of chemicals.

Because of their small size, spider mites have been unpopular for taxonomic or biological studies. Nomenclature has been hard to unravel because of the inadequacy of many older descriptions and the absence of older types.

There is need for more geographical records, ecological studies, and genetic investigations. Such information will undoubtedly alter the classification here proposed and clarify their identification for the economic entomologist.

\section{Sampling}

In checking the orchard a number of separate samples is more desirable than a composite collection. Colonies of mites that look different or appear to have different habits should be collected separately. If the material is submitted to a taxonomic specialist, he will probably mount only several specimens from each collection, and mixed infestations may not be detected.

Samples should not be restricted to mites on leaves. Bryobia may gather daily on the twigs and branches, and beating is necessary to collect specimens under such conditions. During the fall, collections may be desirable from under the bark on the trunk. Weeds in the orchard should not be overlooked.

Whenever it is practical, the most satisfactory method of collecting specimens is to take infested leaves into the laboratory in ice-cream cartons or paper bags. If necessary, the mites may be kept under refrigeration for a week or two. The leaves may then be examined with the aid of a dissecting microscope, and a sample of the spider mites may be obtained with the use of a needle or fine camel's-hair brush. The mites may be placed directly in Hoyer's mounting medium on a slide, or in alcohol for preservation and later mounting.

Care must be taken to select males as well as females, when this is possible. The male is smaller than the female and is pointed posteriorly; often the legs appear proportionately longer.

When it is impractical to make laboratory examinations, infested leaves may be placed directly into a vial of alcohol-from 60 to 80 per cent ethyl alcohol is satisfactory. Care should be taken not to crowd too many leaves into a vial, if this method is chosen.

\section{Slide Prefaration}

Hoyer's is the most practical mounting medium for spider mites. It consists of the following ingredients:

50 grams distilled water

30 grams gum arabic

200 grams chloral hydrate

20 grams glycerine 
The materials should be mixed at room temperature in the sequence listed. Stirring may be necessary over a period of several days.

Live mites or alcoholic specimens may be placed directly into a drop of Hoyer's medium on the slide. Females are ordinarily mounted with the dorsal side up; the legs will straighten out and a certain amount of clearing will take place, if the slide is warmed on a desk lamp after the slide cover is in place. Males must be oriented laterally, and best results are obtained when only one specimen is mounted on a slide. If the slide is heated on a desk lamp before the cover glass is placed, it is easier to compress the male with tiny needles; and a perfect lateral position of the specimen - or at least of the aedeagus - may then be obtained by rolling the cover slip while observations are being made with the compound microscope.

\section{Diagnostic Characters}

The identification of deciduous fruit spider mites with the aid of a compound microscope is attendant on the recognition of differences among a few structures. The high-dry lens gives ample magnification for their discernment in most cases.

The palpus (plate 5) is provided at the tip with a rodlike sensory process, the shape of which is particularly important in separating females of the genus Eotetranychus.

The peritremes (collar tracheae) (plate 6) consist of two divergent arms that arise medially near the anterior end of the body. Their extended position varies as the lobelike base of the mouthparts is everted or retracted. Characteristics of the termination of the peritremes are sometimes important for species recognition.

The fore tarsus bears two pairs of intimately associated setae that are called the duplex setae (plate 5). A single pair of duplex setae is found on tarsus II. The position of the duplex setae or the relative lengths of the members of each pair are sometimes important for identification.

The tibiae and tarsi often bear two types of setae: those that are tactile and which are recognized by being pubescent and tapering to a fine point, and those that are chemosensory and recognized by being nude, thin-walled, and often blunt at the tip. For the sake of convenience, the latter are referred to simply as sensory setae. An oil-immersion lens is usually necessary for the discernment of these two types of setae, but their relative numbers may be important for identification purposes.

The end of the tarsus bears a pair of true claws and a central empodium. The true claw may be clawlike (Bryobia), but it is usually reduced to a pair of knobbed hairs (other genera). The empodium may be represented by a pair of knobbed hairs or a pad bearing two rows of knobbed hairs (Bryobia); it may be clawlike with hairs arising at its base below (Metatetranychus and Paratetranychus), or it may consist merely of divergent hairs (Eotetranychus and Tetranychus, except for leg I of the male).

The caudal end of the body of a spider mite bears setae that are termed the sacrals, lumbars, and postanals (figure 1). A pair of extra setae may be present above the postanals, and these are termed the clunals (figure 1). With a little comparative study, it may be determined whether the clunal setae are 


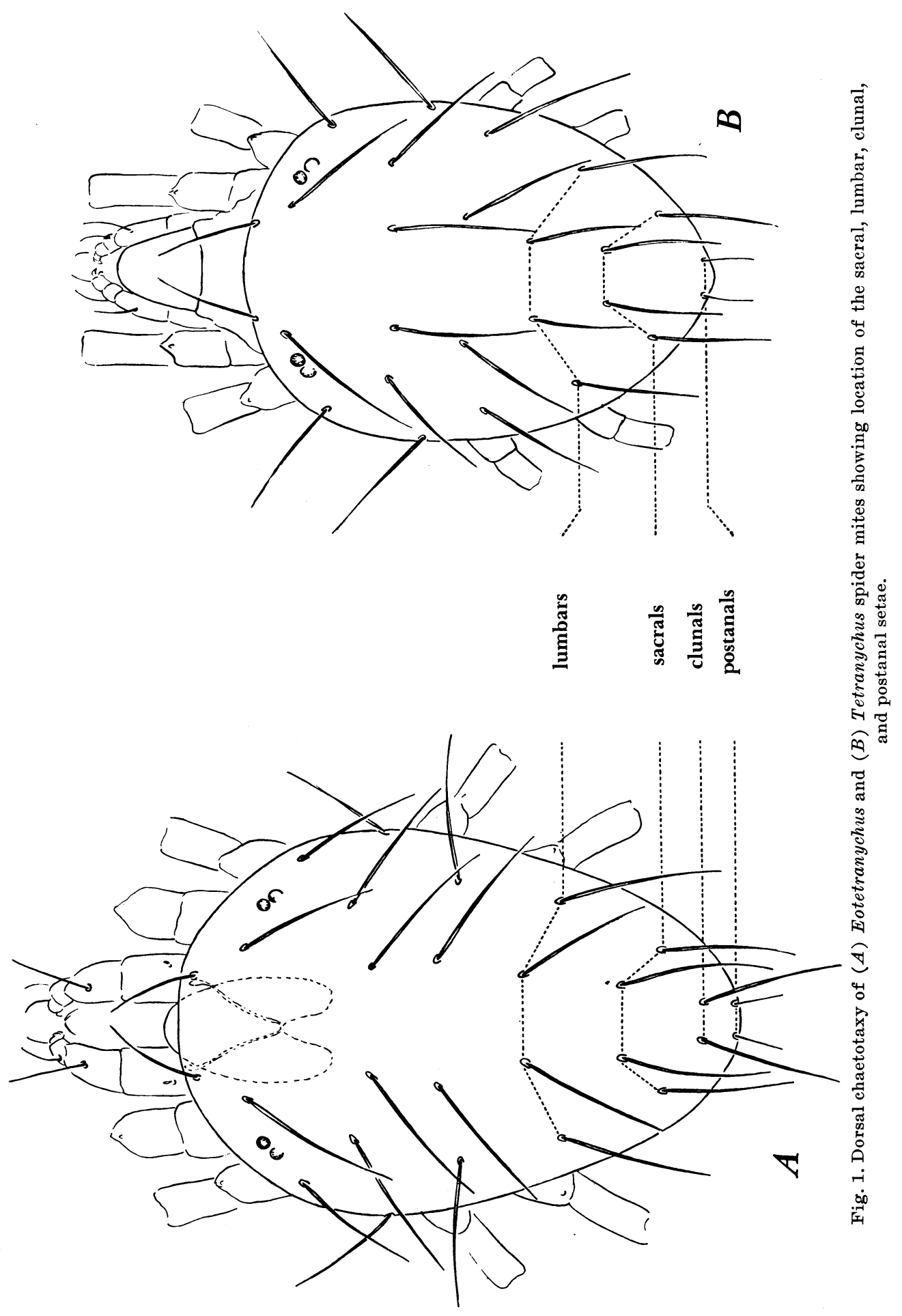




\section{KEY TO SPECIES}

1. Dorsal setae of body long and slender; anterior end of body without projections; true claw consisting only of a pair of knobbed hairs........................

Dorsal setae of body very short and fanlike; anterior end of body with four projections, each bearing a fanlike seta; true claw well-developed, with knobbed hairs medio-

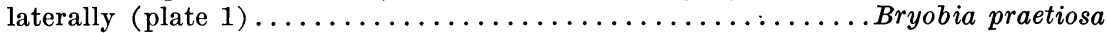

2. Empodium long and clawlike, with ventral hairs at its base (plates 2,3$) \ldots \ldots \ldots \ldots 3$ Empodium (except for leg I of male) consisting only of six paired hairs (plates 4, 9).4

3. Dorsal setae of body set on tubercles; clunal setae present; aedeagus bent upward

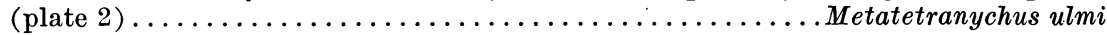

Dorsal setae of body not on tubercles; clunal setae absent; aedeagus bent downward

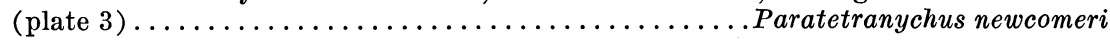

4. Tarsus I with duplex setae set adjacent near end of segment (plate 5); clunal setae present (figure 1); aedeagus very long and slender, with a wave near the middle

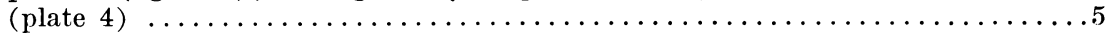

Tarsus I with duplex setae well separated along top of segment (plate 12); clunal setae absent (figure 1); aedeagus bent upward and enlarged at end (plates $8,10,14) \ldots .7$

5. Peritreme with distal end U-shaped (plate 6 )............Eotetranychus uncatus

Peritreme straight distally, terminating in a bulblike enlargement (plate 6 ) ......6

6. Duplex setae of tarsus II with proximal member about one fourth as long as distal member (plate 5); female with terminal sensillum on palpus $2 \frac{1}{2}$ times as long as

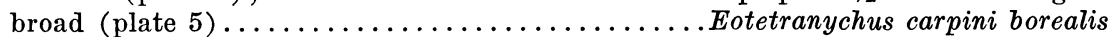

Duplex setae of tarsus II with proximal member about two thirds as long as distal member (plate 5) ; female with terminal sensillum on palpus four times as long as broad

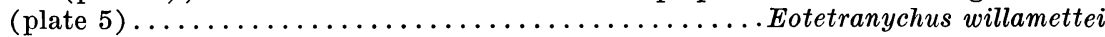

7. Female* with only parallel transverse lines between the inner sacral and inner lumbar

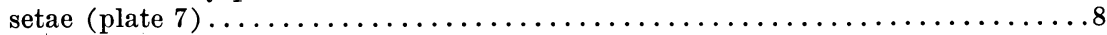

Female with other than parallel, transverse lines on posterior portion between the inner sacral and inner lumbar setae (plates 9,13$) \ldots \ldots \ldots \ldots \ldots \ldots \ldots \ldots$

8. Aedeagus with terminal projection reaching well caudad of level of bend (plate 8)

Tetranychus pacificus

Aedeagus with bent portion S-shaped, the tip reaching caudally only about to level of

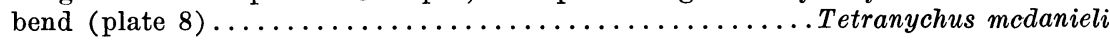

9. Female with parallel, transverse integumentary lines on anterior portion between inner sacrals and inner lumbars, the posterior portion with longitudinal lines (plate 9) ..10

Female with integumentary lines forming a diamond-shaped figure between inner

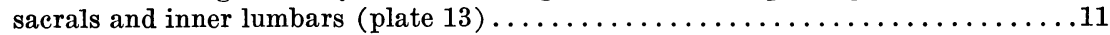

10. Aedeagus with knob strongly enlarged, about one half as long as external portion of shaft (plate 10)............................ Tetranychus schoenei

Aedeagus with knob much smaller, about one fourth as long as external portion of shaft

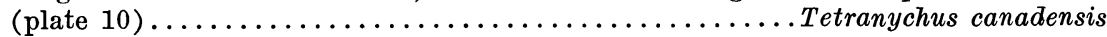

11. Aedeagus with knob comparatively large, its axis often forming an angle with axis of shaft (plate 14)............................ Tetranychus atlanticus

Aedeagus with knob very small, its axis parallel to axis of shaft (plate 14)

Tetranychus bimaculatus

* The species in couplets 8-11 may be identified by reference to figures of the aedeagus, if females are not available and definitely associated. 


\section{FIELD GUIDE TO SPECIES}

\section{Based Primarily on Adult Females}

Precaution: This key is presented as an aid to field identification, primarily for the recognition of genera. The characters given for adult females are based on a number of specimens feeding under average conditions. Teneral females are atypical, and heavily feeding individuals are apt to be more extensively filled with dark spots of pigment in the body.

1. Body convex above, the dorsal setae long and slender; egg, if red, with a dorsal stipe...2 Body flat above, the dorsal setae very short and broad; egg bright red, hemispherical,

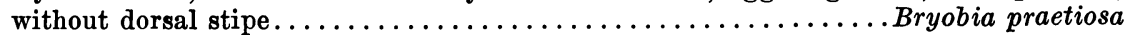

2. Feeding injury on upper side of leaves; overwintering in egg stage............

Feeding injury (except for very severe infestations) on lower side of leaves; overwinter-

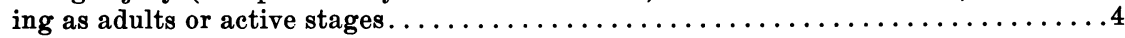

3. Body brick red with the dorsal setae on white tubercles; egg red. .Metatetranychus ulmi

Body purplish except for pink anterior portion, and without white spots or tubercles on dorsum; egg clear or amber................... Paratetranychus newcomeri

4. Tiny, nearly parallel-sided mites; pale yellowish or greenish and often with several pairs of small, dusky, lateral spots; egg pearly, with a fine, dorsal stipe; overwintering

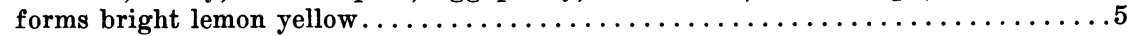

Larger, globular mites; greenish or yellowish with large dark spots or else carmine; egg pearly, without a dorsal stipe; overwintering forms orange $\ldots \ldots \ldots \ldots \ldots \ldots \ldots 6$

5. Western species......................... Eotetranychus carpini borealis Eotetranychus willamettei Eotetranychus uncatus

Eastern species $\ldots \ldots \ldots \ldots \ldots \ldots \ldots \ldots \ldots \ldots \ldots \ldots \ldots \ldots \ldots \ldots$ Eotranychus uncatus

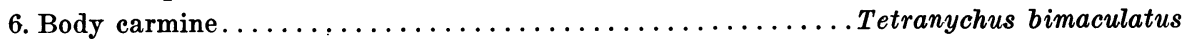

Body greenish or yellowish with dark spots.........................

7. Body with a large dark spot on either side near middle and another pair of conspicuous

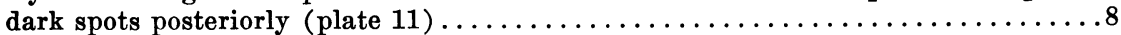

Body without large caudal spots separated from middle spots (plate 15)

Tetranychus bimaculatus Tetranychus atlanticus

8. Western and Midwestern species................... Tetranychus pacificus Tetranychus mcdanieli

Eastern species. Tetranychus schoenei Tetranychus canadensis 
present or not. The pattern of integumentary striations between the inner sacrals and inner lumbars of the female is valuable for determining species groups of the genus Tetranychus.

The final identification in many-but not all-of the species may be found in the shape of the aedeagus. The male must be mounted laterally in order to see the outlines of this simple but often characteristic structure.

\section{TREATMENT OF THE SPECIES}

\section{Bryobia praetiosa Koch}

\section{Clover Spider Mite}

\section{(Plate 1)}

Taxonomic and nomenclatural status. The name Bryobia praetiosa is well known to economic entomologists, and it has been widely used by taxonomic workers. This name should be retained even though several earlier names appear to have priority. There are a large number of synonyms.

Identification. The strongly developed true claws, the short, fanlike setae on the body, and the four protuberances at the anterior end of the body are all characters that will separate $B$. praetios $a$ from other spider mites occurring on deciduous fruits in North America. Males are unknown.

Field recognition. The dark brown to dull greenish body, flattened above and bearing very short setae, serves for field recognition. The front legs of the adult female are comparatively long. The egg is spherical, smooth, and cherry red. Newly hatched larvae are scarlet.

Biological notes. Bryobia praetiosa flourishes during the spring of the year. Summers $(1950 a, b)$ has shown that there are three generations in California during the spring on almonds and that most of the eggs then pass the summer and winter before hatching. In temperate areas such as the coastal area of California and its southern valleys, active stages of Bryobia may be found during the winter; overwintering adults may be found in colder climates.

$B$. praetiosa is a migrant feeder, being found on the upper and lower sides of the leaves and on the twigs. Summers (unpublished data) has shown that there is a definite temperature relationship with movements of the mites on the tree. Bryobia spins no web.

Hosts. Bryobia praetiosa is a particular pest of deciduous fruit trees: apple, pear, plum, prune, cherry, peach, and nectarine. It may be found abundantly, however, on a number of other plants. Almond is a favorite host, and walnut is reported to be a host. Wild or native grasses commonly harbor the mite, as well as wheat, barley, and other grains. Clover and alfalfa are occasionally infested. A number of other plants have been recorded as hosts, including weeds, ornamental bulbs and vines, vegetables, and trees. It commonly invades houses, particularly in the spring.

Distribution. B. praetiosa is widespread throughout North America and Europe. Material has also been examined from South America and South Africa, and authentic records are available from New Zealand, Australia, and North Africa. 


\section{Metatetranychus ulmi (Koch)}

\section{European Red Spider Mite}

(Plate 2)

Taxonomic and nomenclatural status. In most of the North American literature this species has been referred to as Paratetranychus pilosus (Canestrini and Fanzago).

The genus Metatetranychus is differentiated from Paratetranychus by the possession of an extra pair of setae, the clunals, near the caudal end of the body. Metatetranychus has been recognized by most acarologists in Canada, Europe, and Australia, and in our opinion it is a valid genus. M. ulmi (Koch) is the type of the genus.

The trivial name $u l m i$ (Koch), 1836, is based on a description that is fully as diagnostic as that of Canestrini and Fanzago, 1876, for pilosus, even though the illustration is not as well presented as that by Canestrini, 1889 . Ulmus is a favorite host for this species, even in California. There seems to be no justification for not accepting in the United States a name that is in current use throughout most of the world. Metatetranychus ulmi is, therefore, used instead of Paratetranychus pilosus.

Identification. The presence of strong tubercles that bear the dorsal setae of the body will serve for recognition of this species among spider mites on deciduous fruit trees. The true claws are each reduced to a pair of knobbed hairs, and the empodium is clawlike and bears three pairs of hairs at its base. The aedeagus bends upward to form a slender, tapering, S-shaped curve.

Field recognition. The female has a globular body, brick-red with obvious whitish spots at the bases of the strong dorsal setae. This coloration will serve adequately for identification purposes. Teneral females lack the pale spots, and heavily. feeding females sometimes appear greenish. The egg is red, slightly flattened and striate above, and it bears a dorsal stipe.

Biological notes. Metatetranychus ulmi overwinters in the egg stage on the twigs of trees. Ordinarily it builds up slowly during the spring and becomes a serious pest late in the summer. The feeding damage is apparent on the upper side of the leaves, and very little or no webbing is spun.

Cagle (1946) has presented one of the best studies on the life history of this mite in the United States, although many other workers have made significant contributions. Among other biological studies that may be mentioned are those of Newcomer and Yothers (1929), Gilliat (1935), Garman and Townsend (1938), Hey (1944), and Andersen (1947). Groves and Massee (1951) present an extensive, annotated bibliography of $M$. ulmi.

Hosts. Metatetranychus ulmi is found predominantly on deciduous bushes and trees belonging to the family Rosaceae. Fruit trees, namely apple, cherry, pear, peach, plum, and prune, are common hosts. Berries, as well as the ornamental shrubs cotoneaster and pyracantha, often serve as hosts. Almond, walnut, elm, mountain ash, and black locust are also subject to attack.

Distribution. M. ulmi appears to be principally holarctic in distribution; it is common in both North America and Europe. Apparently authentic records are available from New Zealand and Tasmania, although it is not known from the Australian mainland. 


\section{Paratetranychus newcomeri McGregor}

\section{Newcomer Spider Mite}

(Plate 3)

Taxonomic status. Paratetranychus newcomeri is very closely related to $P$. viridis (Banks), a species that occurs on deciduous trees in eastern North America. It has been regarded as distinct because of a slight difference in the aedeagus. $P$. newcomeri may prove to be a variation or a subspecies of $P$. viridis.

Identification. On deciduous fruits, $P$. newcomeri resembles $M$. ulmi, but the dorsal setae of the body are not borne on tubercles. The empodial claw bears four pairs of hairs rather than three, and the clunal setae are absent. The most obvious difference between these two species is that the aedeagus of $P$. newcomeri bends down rather than up.

Field recognition. $P$. newcomeri may be recognized by being globular with long dorsal setae, and purplish with a somewhat heartshaped, pinkish area anteriorly. The anterior legs are pale like the anterior portion of the body, and the posterior legs are somewhat darker. It feeds on the upper surface of the leaves. The egg is strongly flattened and striate above, and it bears a dorsal stipe; summer eggs are pale until a day or two prior to hatching, and winter eggs are amber.

Biological notes. $P$. newcomeri, like related species in the genus Paratetranychus, overwinters in the egg stage. Its feeding damage is apparent on the upper side of the leaf. Very little webbing is spun.

Hosts and distribution. $P$. newcomeri is known to occur on pears, and it has been transferred to apple in the laboratory. It is not yet known to be of economic significance. The species is known only from the Yakima Valley, Washington.

\section{Eotetranychus carpini borealis (Ewing), new combination Yellow Spider Mite}

$$
\text { (Plates 4, 5, 6) }
$$

Previously known as Tetranychus borealis Ewing.

Taxonomic and nomenclatural status. Specimens here referred to under the name Eotetranychus carpini borealis were included with others for many years under the name Tetranychus willamettei McGregor. Recently, McGregor (1950) included such specimens, along with others, under the name Tetranychus flavus Ewing; while T. borealis was listed separately but considered possibly to be the same as $T$. flavus.

The genus Eotetranychus is differentiated from the genus Tetranychus by the possession of an extra pair of setae, the clunals, near the posterior end of the body. Moreover, the duplex setae on tarsus I are adjacent rather than being widely separated. This generic distinction is not the same as that of McGregor (1950), who based his conception of Eotetranychus on the pattern of integumentary striations on the dorsum of the female.

The types of $T$. borealis Ewing, 1913, p. 457, resemble the types of $T$. flavus Ewing, 1913, p. 458. The revised international rules of zoological no- 
menclature make page priority mandatory, and borealis, therefore, takes precedence over flavus. Other new synonymy, based on a study of types, includes Tetranychus oregonensis MeGregor, 1914, and Tetranychus monticolus MeGregor, 1914.

The types of borealis and other representatives of this form have been compared with specimens from Carpinus betulus in England that represent Eotetranychus carpini (Oudemans), 1905. The only difference detected between material referable to borealis and carpini is in the chaetotaxy of tibia I of the male. This difference may be due to variation or it could represent a real species difference. Because a morphological distinction, even though very small, can be demonstrated with the material studied and because a geographical distinction is evident, it appears advisable to employ separate names. In view of the nature of the difference found between carpini and borealis and in order to show the close relationship of the two forms, it is proposed to treat them as subspecies.

Identification. $E$. carpini and closely related species, $E$. willamettei and $\boldsymbol{E}$. uncatus, are distinctive in having the aedeagus very slender, pointed, and with a distinct wave near the middle (plate 4 ).

In E. carpini, as well as $E$. uncatus, the proximal pair of duplex setae of tarsus I has the proximal member less than one fourth as long as the distal member, and the proximal member of the duplex setae on tarsus II is about one fourth as long as the distal member (plate 5). E. carpini, as well as $E$. uncatus, further differs from $E$. willamette $i$ in having the terminal sensillum on the palpus of the female stout, about two and one half times as long as broad (plate 5).

$E$. carpini (and $E$. willamettei) differ from $E$. uncatus in having the peritreme ending in a simple, bulblike enlargement (plate 6).

$E$. carpini borealis differs from $E$. carpini carpini in that tibia I of the male possesses 4 sensory setae rather than 2 (or 1 ) along with the 9 tactile setae.

Field recognition. $E$. carpini borealis, as well as a number of related mites belonging to the genus Eotetranychus, are very small and slender, flesh to pale yellowish or greenish in color, and usually with 2 or 3 pairs of small, dusky spots on the body in later life. The eggs are spherical and clear with a fine dorsal stipe. Feeding injury under the leaves somewhat resembles mildew spots. Specimens must be mounted for accurate determination.

Biological notes. $E$. carpini borealis overwinters as bright lemon-yellow females, particularly under the bark of trees. Active stages feed principally along the midrib and veins underneath the leaf, producing a number of small colonies when not too abundant. Very little webbing is produced. O'Neill and Weeks (1951) summarized biological studies of this mite in Washington. According to observations by E. J. Newcomer, this subspecies has a tendency to be active later in the fall than is the case with species of Tetranychus; also, it tends to hibernate farther from the ground:

Hosts and distribution. E. carpini borealis is a pest of apples and pears in the Pacific Northwest. Other hosts include cherry, raspberry, blueberry, spirea, alder, and willow. It has not been found on grapes. The subspecies occurs commonly along the Pacific Coast, from British Columbia to northern California. 


\section{Eotetranychus willamettei (McGregor), new combination Willamëtte Spider Mite}

(Plate 5)

Previously known as Tetranychus willamettei MeGregor.

Taxonomic and nomenclatural status. $E$. willamettei was until recently the name applied to this and closely related species in North America. However, McGregor (1950) considered willamettei to be a synonym of $\boldsymbol{T}$. flavus (see $\boldsymbol{E}$. carpini borealis). It is here regarded as a distinct species.

Identification. $E$. willamettei differs from both $E$. carpini and $E$. uncatus in that the female palpus bears terminally a sensory rodlike process that is slender, about four times as long as broad. Moreover, each pair of duplex setae on tarsi I and II has the proximal member much longer than in those species. On tarsus I the proximal member of the more proximal pair of duplex setae is about one half as long as the distal member, and on tarsus II the proximal member of the duplex setae is at least two thirds as long as the distal member.

The aedeagus of $E$. willamettei closely resembles that of $E$. carpini and $E$. uncatus, and the chaetotaxy of tibia I of the male is as in E. carpini borealis. The peritreme ends in a simple bulb as in E. carpini.

Field recognition. The general appearance of actively feeding mites, overwintering females, and eggs are all similar to $E$. carpini and $E$. uncatus. Feeding characteristics are also similar.

Biological notes. Frazier and Smith (1946) and L. M. Smith (1950) reported that the Willamette spider mite appears on grapes in great numbers during the spring in California, but that populations rapidly decline by early summer and are not seen again until the following spring. The biology of this mite is discussed in more detail in both articles, and the effect of sulfur and predators on the summer populations is considered in the latter paper.

Hosts. $E$. willamette $i$ is a serious pest of grapes in California. It has been found on apple trees in southern and north-central California and in Yakima, Washington. Wild hosts include antelope brush (Purshia tridentata), box elder (Acer negundo californicum), service berry (Amelanchier sp.), and Quercus garryana (referred to in the original description as Q. lobata). Specimens have also been submitted from barley and rye.

Distribution. E. willamette $i$ is known only from the western states of California, Oregon, Utah, and Washington; and also from British Columbia, Canada.

\section{Eotetranychus uncatus Garman, new species}

\section{Garman Spider Mite}

(Plates 5, 6)

Taxonomic status. $E$. uncatus is a newly recognized species.

Identification. $E$. uncatus is closely allied to $E$. carpini and $E$. willamettei, but differs from both by having the distal end of the peritreme strongly Ushaped.

The following description was prepared by Philip Garman for inclusion in the present article. 
Female. Flesh-colored or pale lemon yellow, sometimes nearly white, usually with small black dots along body behind the eyes (sometimes as many as four distinctly visible). Winter form distinctly lemon yellow. Palpus with terminal sensory peg stout, two and one half times as long as broad (plate 5). Peritreme strongly hooked distally, with several terminal chambers (plate 6 ). Tibia I with 10 setae ( 9 tactile and 1 sensory) ; tarsus I with 5 tactile setae and 1 sensory seta proximal to duplex setae; proximal duplex setae of tarsus I with proximal member about one fourth as long as distal member; distal duplex setae of tarsus I with proximal member about one sixth as long as distal member. Tibia II with 8 tactile setae only. Body with dorsum transversely striate except anteromedially; dorsal setae longer than intervals between bases, slender, tapering, and pubescent. Length of body 330 to $440 \mu$; greatest width of body 200 to $270 \mu$.

Male. Dots along body inconspicuous or absent. Palpus with terminal sensillum very slender, four times as long as broad. Peritremes as in female. Tibia I with 10 setae (however, usually with 9 tactile and 2 sensory setae, plate 5); tarsus I with 4 tactile and 3 sensory setae proximal to duplex setae, the duplex setae as in female; empodium I with digits shorter and stouter than in female. Tibia II and tarsus II with chaetotaxy as in female. Body with dorsal striae and setae similar to female. Aedeagus long, attenuate, and sharply pointed, undulate just beyond the middle, and with tip extending noticeably beyond end of abdomen. Length of body 290 to $320 \mu$; greatest width of body $150 \mu$.

Holotype. Male, Amherst, Massachusetts, June 13, 1949, E. H. Wheeler, on apple leaves; in the collection of the Connecticut Agricultural Experiment Station.

Paratypes. Fifteen males, 69 females, Amherst, Massachusetts, June 9, 1949, E. H. Wheeler, on apple; 15 females, East Haddam, Connecticut, December 28, 1949, W. T. Brigham, on apple bark ; 3 males, 14 females, Lebanon, Connecticut, July 7, 1950.

Field identification. $E$. uncatus closely resembles $E$. carpini borealis and $E$. willamette $i$ with regard to the appearance of eggs, immature stages, summer and hibernating forms, and feeding characteristics. Specimens must be mounted for accurate determination.

Biological notes. E. H. Wheeler observed that, "In feeding on the undersurface (of the leaves) they seem to cause an uneven growth of the two surfaces of the leaf, thus causing a cupping or crinkling of the leaf from below. In heavy infestations the entire area along the two sides of the midrib and isolated areas on other parts of the leaf are affected this way. This mite overwinters as the adult female-entirely on the tree. Clusters of the females can be found under loose bark all the way from the very base of the trunk up the limbs as far as the loose flakes of bark occur. These females start to become active at the delayed or late delayed dormant stage of McIntosh bud development. At this time on a warm day these mites can be said to swarm out of their winter quarters and make their way over the limbs and branches to the spur leaves. Growers and others have confused the spur leaf injury with frost injury in many instances. It seems necessary for the overwintering females to feed several days before egg-laying gets under way. During two seasons, 
hatching of these earliest eggs has occurred just before the true calyx or petal-fall condition. It seems that the egg-laying period coincides very closely with the hatching period of the European red mite."

Hosts and distribution. $E$. uncatus is known primarily from apple in Massachusetts and Connecticut. According to Dr. Garman, it was originally discovered by J. G. Conklin, of New Hampshire, in 1949. Apparently identical specimens were taken at Logan, Utah, September 20, 1949 (G. F. Knowlton and A. C. Valcarce), on white birch.

\section{Tetranychus pacificus McGregor}

\section{Pacific Spider Mite}

(Plates 7, 8)

Nomenclatural status. The application of the name Tetranychus pacificus is clear, and no synonyms are known.

Identification. $T$. pacificus belongs to that species group of the genus Tetranychus in which only transverse striae are present between the inner sacral and inner lumbar setae of the female (plate 7). They are indistinguishable from females of $T$. mcdanieli. The aedeagus (plate 8 ) is distinctive in having at its distal end a long, posteriorly tapering angulation that reaches well beyond the level of the upward bend (well beyond a line drawn at right angles to the axis of the shaft).

Field recognition. Active females are greenish to yellowish in color with a large, dark spot on each side near the middle and another pair of dark spots near the caudal end. Feeding is general over the undersurface of leaves, and dense webbing may be produced. Eggs are spherical, pearly white. Overwintering females are bright orange, usually occurring under the bark of trees or in litter on the ground.

Biological notes. T. pacificus ordinarily overwinters as hibernating females, and it is often summer before it builds up in sufficient numbers to cause defoliation. However, in the San Joaquin Valley, California, many Pacific spider mites appeared to continue reproduction on vetch during the winter of 1950-51, and destructive populations were present in the spring for newly planted crops such as cotton.

Hosts. T. pacificus is one of the most serious pests of deciduous fruits in the western United States: apple, pear, plum, prune, peach, nectarine, apricot, and cherry are all subject to attack. It is also a serious pest of other crops such as almond, walnut, grape, fig, cotton, alfalfa, ladino clover, vetch, melons, beans, and blackberry. A number of other plants serve as hosts, including various weeds such as sunflower, tarweed, morning glory, milkweed, salvia, and pigweed; shrubs such as cotoneaster, mountain mahogany, Garrya flavescens, and Ceanothus sp.; and trees such as black locust and elm. It has also been noted as a pest of maize.

Distribution. T. pacificus is known to occur throughout the west coast area from southern California to British Columbia. At least in California, it occurs predominantly in the hot interior valleys and dry mountain ranges; it is rare along the coast. 


\section{Tetranychus mcdanieli McGregor}

\section{McDaniel Spider Mite}

(Plate 8)

Taxonomic and nomenclatural status. The application of the name $T$. mcdanieli is clear, although the species may have been confused with T. pacificus. It is possible that future studies may indicate that $T$. mcdanieli actually represents only a subspecies or possibly a variant of $T$. pacificus.

Identification. T. mcdanieli differs from T. pacificus only in that the aedeagus bends upward distally to form a curve ending at a caudal level that is about even with the caudal level of the upward bend (nearly even with a right angle to the axis of the shaft) ; also, the portion bending upward is narrower (plate 8). Many males are distinctive in that the upward curve is tapering from the base, but other males bear an anterior angulation on the curve resembling the angulation that is always found on the aedeagus of $T$. pacificus; these males are sometimes more difficult to determine with certainty.

Field recognition. T. mcdanieli resembles $T$. pacificus very closely in all respects as far as field recognition is concerned.

Biological notes. T. mcdanieli was described from raspberries in Michigan, in 1931. It was not recognized elsewhere until it was taken on raspberries in Utah, in 1948. Subsequently it has been found to be a serious pest of deciduous fruits in localized areas in the Pacific Coast states.

Although no detailed biological investigations have been made, $T$. mcdanieli appears to be very similar to T. pacificus as far as field habits are concerned.

Hosts and distribution. T. mcdanieli is recognized as an important, localized pest of apples, plums, and prunes. It is also known to attack raspberries. Its distribution is known from Michigan and North Dakota in the Midwest, and from British Columbia, Washington, Utah, and California in the West. Females have been examined from Colorado and Texas, representing either $T$. medanieli or T. pacificus.

\section{Tetranychus schoenei McGregor}

\section{Schoene Spider Mite}

(Plates 9, 10)

Taxonomic and nomenclatural status. Tetranychus schoenei was transferred by McGregor (1950) to the genus Septanychus, because a rudimentary spur was detected above the empodial hairs. This character is not considered by us to be worthy of generic significance.

The genus Septanychus McGregor, 1919, was originally based on an obvious empodial spur above the empodial hairs of mites otherwise referable to Tetranychus. Recently the same author has transferred to or described species in the genus Septanychus on the basis of a rudimentary empodial spur. This very tiny spur, however, is characteristic of all species of the genus Tetranychus, including the type of the genus here referred to provisionally as $T$. bimaculatus. 
Identification. The female of $T$. schoenei bears transverse striae on the integument between the inner lumbar setae and on the anterior half of the area behind them and the inner sacral setae (plate 9). The posterior half of this area, however, bears longitudinal striae that pass between the inner sacrals. They are indistinguishable from females of $T$. canadensis.

The aedeagus is distinctive in being strongly enlarged at the end, the terminal width being about one half as long as the external shaft (plate 10). The terminal knob is broadly rounded anteriorly, and the caudal projection is strong but narrowing to a point that curves downward.

Field recognition. T. schoenei appears to be very similar to T. canadensis with which it may be associated in the field. It is similarly greenish with dark "shoulder" spots and "tail" spots, and the overwintering females are bright orange. This is also characteristic of T. pacificus and T. mcdanieli. Males must be mounted for accurate determination.

Biological notes. Cagle (1943) presents an excellent biological account of $T$. schoenei. This species appears to be similar to T. pacificus with regard to summer and winter coloration, webbing and feeding habits, as well as seasonal development.

Hosts and distribution. Apple is known to be a host on which T. schoenei is destructive. Cotton, beans, Rubus, and black locust are also hosts. T. schoenei is known to occur in Virginia, West Virginia, and Alabama. Apparently it is a species worthy of economic consideration throughout the southeastern United States.

\section{Tetranychus canadensis (McGregor), new combination}

\section{Four-spotted Spider Mite}

(Plates 10, 11)

Recently deseribed as Septanychus canadensis McGregor, 1950.

Taxonomic and nomenclatural status. The application of the name Tetranychus canadensis is clear, although this species was previously referred to the genus Septanychus. The rudimentary empodial spur of this species is not . considered by us to be a character of generic value (see Tetranychus schoenei).

Identification. $T$. canadensis is closely allied to $T$. schoene $i$, and the female similarly possesses transverse, parallel striae immediately behind and between the inner lumbar setae and longitudinal striae in front of and between the inner sacrals.

The aedeagus of canadensis is distinguished from schoenei in that its knobbed end is comparatively small, less than one fourth as long as the external shaft (plate 10).

Field identification. T. canadensis is very similar to $T$. schoenei with which it may be associated in the field (plate 11).

Biological notes. Lienk and Chapman (1951) state that T. canadensis resembles T. bimaculatus with regard to biology and that there are approximately eight generations annually in New York. More-detailed biological studies are being made by these authors. 
Hosts and distribution. T. canadensis is known from apple, elm, and horse chestnut. It was described from Ontario, Canada. It is now known to occur in New York, New Jersey, Washington, D.C., Indiana, and, in association with T. schoenei, in Virginia.

\section{Tetranychus bimaculatus Harvey}

\section{Two-spotted Spider Mite}

(Plates 12, 13, 14, 15)

Nomenclatural status. Tetranychus bimaculatus Harvey, 1898, is the oldest name based on North American specimens that can be applied to the twospotted spider mite. However, this species is also common in Europe (and elsewhere) where a large number of proposed names have priority. Tetranychus telarius Linnaeus, 1758 , was the name most commonly used by economic entomologists for this species in North America until 1944, and it is also in use abroad; there are very good arguments both for using and rejecting this name for the mite. Tetranychus urticae Koch, 1836, is a name that is in common use for this species in Europe and elsewhere. Tetranychus altheae Trägårdh, 1902, is still another name that has been used by a number of workers.

Careful consideration is being given to the determination of the appropriate scientific name for this species. At the present it appears probable that Tetranychus sambuci (Schrank), 1781, is the oldest name available, if telarius is to be used as the trivial name for a species that commonly infests linden in Europe. A decision on the appropriate name, however, is being held up pending more thorough investigation.

Color forms. It has been evident to a number of workers that there are two basic color forms of $T$. bimaculatus: the greenish, two-spotted form (the only one found in Oregon by Ewing, 1914, and in West Virginia by Cagle, 1949) and the carmine form (the predominant one found in South Carolina and other southeastern states by McGregor and MeDonough, 1917). All other known species in the genus Tetranychus represent color forms comparable to one or the other of these two.

Females of the green, two-spotted form vary from yellowish to brownish or nearly black, apparently in association with host differences and feeding activities. The hibernating females of the green form are orange, and hibernating females of the carmine form are reported also to be more or less orange.

The carmine form of T. bimaculatus was employed by Davis (in press) for cross-mating experiments with Tetranychus multisetis McGregor, 1950 (always carmine in color). Although direct comparisons were not made in the original deseription of $T$. multisetis, it was actually differentiated from $T$. bimaculatus only on a basis of possessing six, rather than four, setae proximal to the duplex setae on tarsus I of the female (plate 12).

Davis showed that representatives identifiable as T. multisetis and $T$. bimaculatus cross-mated as readily as specimens of both sexes referable to each name, and he was able to produce many generations from the crosses by interbreeding the progeny. 
The geographical occurrence of T. multisetis and that of the carmine form of $T$. bimaculatus in the southern United States appear to be the same (including introductions into northern greenhouses, as a rule). Accordingly, $T$. multisetis cannot be regarded as a distinct species and must be relegated to synonymy.

It is interesting to note that in the Davis experiments (and confirmed by the mating studies of $\mathrm{Keh}$ ), the female progeny of the $\mathrm{F}_{1}$ and succeeding generations always resembled the mother with regard to the chaetotaxy of tarsus I, regardless of the type of male with which the crosses were made.

In another series of experiments, Keh (unpublished) made a series of crosses of the T. multisetis carmine form with the green-colored form of $T$. bimaculatus. As a result of these matings, females were readily produced in the $F_{1}$ generation-indicating that fertilization had taken place, since unfertilized females produce only males. However, in contrast to the checks, most of the inbred $F_{1}$ females produced unviable eggs. It was thus indicated that the colonies represented two nearly distinct populations, and that subspecies or species were involved. Carmine forms referable to T. bimaculatus, however, have not been crossed with the green forms, and this is desirable.

Morphological characters have not been detected that will always distinguish the green form from the carmine form of $T$. bimaculatus. The green form is found throughout the northern part of the United States, and it is found associated with the carmine form in the southern United States. The carmine form is found in the southeastern and far southwestern United States (and occasionally as introductions in northern greenhouses). Although the range of the two color forms overlaps, they appear to be largely allopatric, and it appears practical to refer to them as subspecies. Because of the present uncertainty of scientific names, however, subspecific names are not proposed.

Neiswander et al. (1950) showed that the green and the carmine forms react differently to acaricides, and correspondence from several other workers has confirmed the distinction. Accordingly, economic entomologists should note the color form with which they are working until it is possible to use diagnostic names.

Seasonal phases. Oudemans, the great Dutch acarologist, noted that the integumental striations of mites belonging to the genus Tetranychus may differ according to whether the striae are broken or solid. He considered the difference to be of value for species recognition, and Geijskes (1939) followed Oudemans in accepting this distinction in his monograph of the spinning mites of Europe.

Laboratory studies, together with microscopic examination of a large number of specimens collected at various times of the year, have shown that the integument of hibernating spider mites differs from that of actively feeding forms - the striations are solid in the former and broken in the latter (plate 13). Laboratory experiments have failed to produce the solid integumentary striae from dotted striae by merely subjecting the mites to cold temperatures. Furthermore, the solid-type striae have been noted during the winter on mites from greenhouses that were maintained at a minimum of $70^{\circ} \mathrm{F}$. These solid-striae mites, however, were always on the older leaves (with actively feeding, dotted-striae phase mites on the new growth), and it is believed that 
the condition of the host plant is the major factor for determining diapause.

All mites belonging to the genera Tetranychus and Eotetranychus that are found in northern climates appear to be susceptible to this change in integumentary striation. It is possible that such an obvious morphological transition might be correlated with some chemical change that alters the susceptibility of these mites to a given acaricide.

Identification. The female of $T$. bimaculatus is characterized by having a diamondshaped figure formed by the integumentary striae between the inner sacrals and inner lumbars (plate 13). This is also characteristic of T. atlanticus and a number of species that are not known to occur on deciduous fruit trees.

The aedeagus of bimaculatus is distinctive in that it bends upward and bears at its tip a very small knob, the axis of which is parallel to that of the shaft (plate 14).

Field recognition. Active females of $T$. bimaculatus are comparatively large, globular mites, greenish to flesh-colored, yellowish, or sometimes brownish with a prominent dark spot on each side near the middle of the body-the spots may enlarge to cover most of each side of the body as the mite feeds (plate 15). This coloration is also characteristic of T. atlanticus. Overwintering females are dull orange as in T. atlanticus.

T. bimaculatus may also be carmine, but this color form does not ordinarily occur outdoors in the northern United States ; however, it resembles a number of other species (not known from deciduous fruits) in the southern United States.

Eggs are spherical and pearly white, without a dorsal stipe. Feeding may start in restricted colonies on the undersides of leaves, but the mites spread rapidly to cover the leaves below. A moderate amount of webbing is produced.

Biological notes. Cagle (1949) has presented one of the best life history studies of the two-spotted spider mite in recent years, and the earlier work of Ewing (1914) is worthy of special mention. McGregor and McDonough (1917) studied the mite in the southeastern United States.

When suitable hosts are available, $T$. bimaculatus may continue to be active throughout the year, but inactive females are found commonly during the winter. Ordinarily the two-spotted spider mite multiplies in deciduous fruit orchards during the spring on weeds and sucker growth and invades the trees as the summer advances.

Hosts. Deciduous fruit trees are commonly attacked by T. bimaculatus: apple, pear, peach, nectarine, plum, prune, apricot, and cherry are all subject to infestation. Walnuts and almonds are favorable hosts. Many vegetables, berries, hops, cucurbits, and cotton may be seriously affected. A great many weeds, flowering plants, ornamental shrubs, vines, and trees are also commonly infested.

Distribution. T. bimaculatus is widespread throughout most of North America and Europe. It is seldom found in Texas, and the carmine form predominates in the southeastern United States and in localized areas of southern California. The carmine form appears to prevail in Hawaii, as well as in Spain, Palestine, Egypt, and other areas along the Mediterranean. Specimens of T. bimaculatus from Australia and South Africa also have been studied. 


\section{Tetranychus atlanticus McGregor}

\section{Atlantic Spider Mite}

(Plate 14)

Nomenclatural status. The application of the name Tetranychus atlanticus is clear, and no synonyms are known.

Identification. The female of $T$. atlanticus is similar to T. bimaculatus in that the integumentary striations form a diamondshaped figure between the inner sacral and inner lumbar setae. No characters have been found to separate the females of these two species.

The aedeagus of T. atlanticus may be differentiated from that of T. bimaculatus in that the knobbed distal end is much larger, and the axis of the knob often forms a distinct angle with the axis of the aedeagal shaft (plate 14).

Field recognition. Active females of $T$. atlanticus appear very similar to those of the green form of T. bimaculatus in the field. They are often fleshcolored, sometimes greenish or pale yellowish, with a large dark spot on each side near the middle. The eggs are similarly pearly white, spherical. Males must be mounted for definite identification.

Biological notes. T. atlanticus feeds in restricted colonies underneath the leaves, sometimes producing characteristic blotches. A comparatively few mites will cause the leaves to fall. They produce a moderate amount of silk webbing. Ordinarily they overwinter as orange females, similar to those of T. bimaculatus.

Hosts. T. atlanticus is found primarily on low-growing hosts such as cotton, alfalfa, beans, clover, and strawberries. It also occurs on vegetables such as eggplant, and ornamentals such as privet, violet, and sunflower. Peach, pear, plum, apple, walnut, and lemon are also known to be infested.

Distribution. Tetranychus atlanticus is found throughout the United States. It has been recognized in Washington, Oregon, Idaho, Utah, and California as a dominant pest. Collections from the eastern United States have shown that it occurs also in New York, Connecticut, Maryland, Delaware, Virginia, Georgia, Florida, Alabama, Mississippi, Ohio, and Wisconsin.

\section{ACKNOWLEDGMENTS}

The present guide was prepared with the aid of a number of entomologists acquainted with the spider mite pests of deciduous fruits. R. W. Burrell and E. J. Newcomer, USDA Deciduous Fruit Laboratory at Yakima, Washington, reviewed the manuscript and offered many suggestions. Arthur D. Borden, Martin M. Barnes, and Francis M. Summers, University of California at Berkeley, Riverside, and Davis, respectively, all made valuable suggestions. Philip Garman, University of Connecticut, submitted the description of a previously unrecognized species, and E. H. Wheeler, University of Massachusetts, contributed biological data regarding this species. J. Owen Evans, British Museum (Natural History), London, loaned specimens of Eotetranychus carpini, determined by Hirst, for comparative study.

A number of entomologists contributed specimens for identification and study, and still others critically reviewed the manuscript. To all of these co-workers we are very grateful. 


\section{LITERATURE CITED}

Andersen, V.S.

1947. Untersuchungen über die Biologie und Bekämpfung der Obstbaumspinnmilbe Paratetranychus pilosus Can. et Fanz. 118 p. Dissertation Universität Bonn.

Borden, Arthur D., and Harold F. Madsen

1951. Spider mite control-acaricides show selectivity on apples and pears in northern California. Calif. Agr. 5(3):6, 14 .

CAgLe, L. R.

1943. Life history of the spider mite Tetranychus schoenei MeG. Va. Agr. Expt. Sta. Tech. Bul. 87:1-16.

1946. Life history of the European red mite. Va. Agr. Expt. Sta. Tech. Bul. 98:1-19.

1949. Life history of the two-spotted spider mite. Va. Agr. Expt. Sta. Tech. Bul. 113: $1-31$.

Ewing, H. E.

1914. The common red spider or spider mite. Oreg. Agr. Col. Expt. Sta. Bul. 121:1-95.

Frazier, Norman W., and Leslie M. Smith

1946. The Willamette mite on grapes. Hilgardia 17(4):191-95.

Garman, PhiliP

1940. Tetranychidae of Connecticut. Conn. (State) Agr. Expt. Sta. Bul. 431:1-88.

Garman, P., and J. F. Townsend

1938. The European red mite and its control. Conn. (State) Agr. Expt. Sta. Bul. 418: $1-34$.

Groves, JoAn R., and A. M. MASSEe

1951. A synopsis of the world literature on the fruit tree red spider mite Metatetranychus ulmi (C. L. Koch, 1835) and its predators. 180 p. Commonwealth Institute of Entomology, London.

GeiJskes, D. C.

1939. Beiträge zur Kenntnis der europäischen Spinnmilben (Acari, Tetranychidae), mit besonderer Berücksichtigung der niederländischen arten. Mededeelingen van de Landbouwhoogeschool te Wageningen (Nederland) $42(4): 1-68$.

GilliatT, F. C.

1935. The European red mite (Paratetranychus pilosus C. \& F.) in Nova Scotia. Canad. Jour. Res. Sect. D, Zool. Sci. 13:1-17.

HeY, G. L.

1944. Observations on the life history of the fruit tree red spider and its control. Fruit Grower 97:66, 70, 101-02, 199-200, 313-14, 387-88, 423-24.

Lienk, S. E., and P. J. ChAPMAN

1951. Orehard mite studies in 1950. Jour. Econ. Ent. 44(3):301-06.

MCGREGOR, E. A.

1950. Mites of the family Tetranychidae. Amer. Midland Nat. 44(2):257-420.

MCGRegor, E. A., and F. L. MCDONOUGH

1917. The red spider on cotton. U. S. Dept. Agr. Bul. 416:1-72.

Neiswander, C. R., J. G. Rodriguez, and R. B. Neiswander

1950. Natural and induced variations in two-spotted spider mite populations. Jour. Econ. Ent. 43(5):633-36.

NEWCOMER, E. J., and M. A. YoThers

1929. Biology of the European red mite in the Pacific Northwest. U. S. Dept. Agr. Tech. Bul. 89:1-69.

O'NeILl, W. J., and G. W. WeEKS

1951. Thorough coverage necessary to control Willamette mite. Better Fruit 45(8):7.

Summers, Francis M.

1950a. New data on brown almond mite. Almond Facts 14(2):8.

$1950 \mathrm{~b}$. Brown almond mites-overwintering eggs appear in June with three life cycles a year offering an advantage in control program. Calif. Agr. 4(7):6.

SMith, LeSLie M.

1950. Mite populations on grapes. Calif. Agr. 4 (3):13-14. 

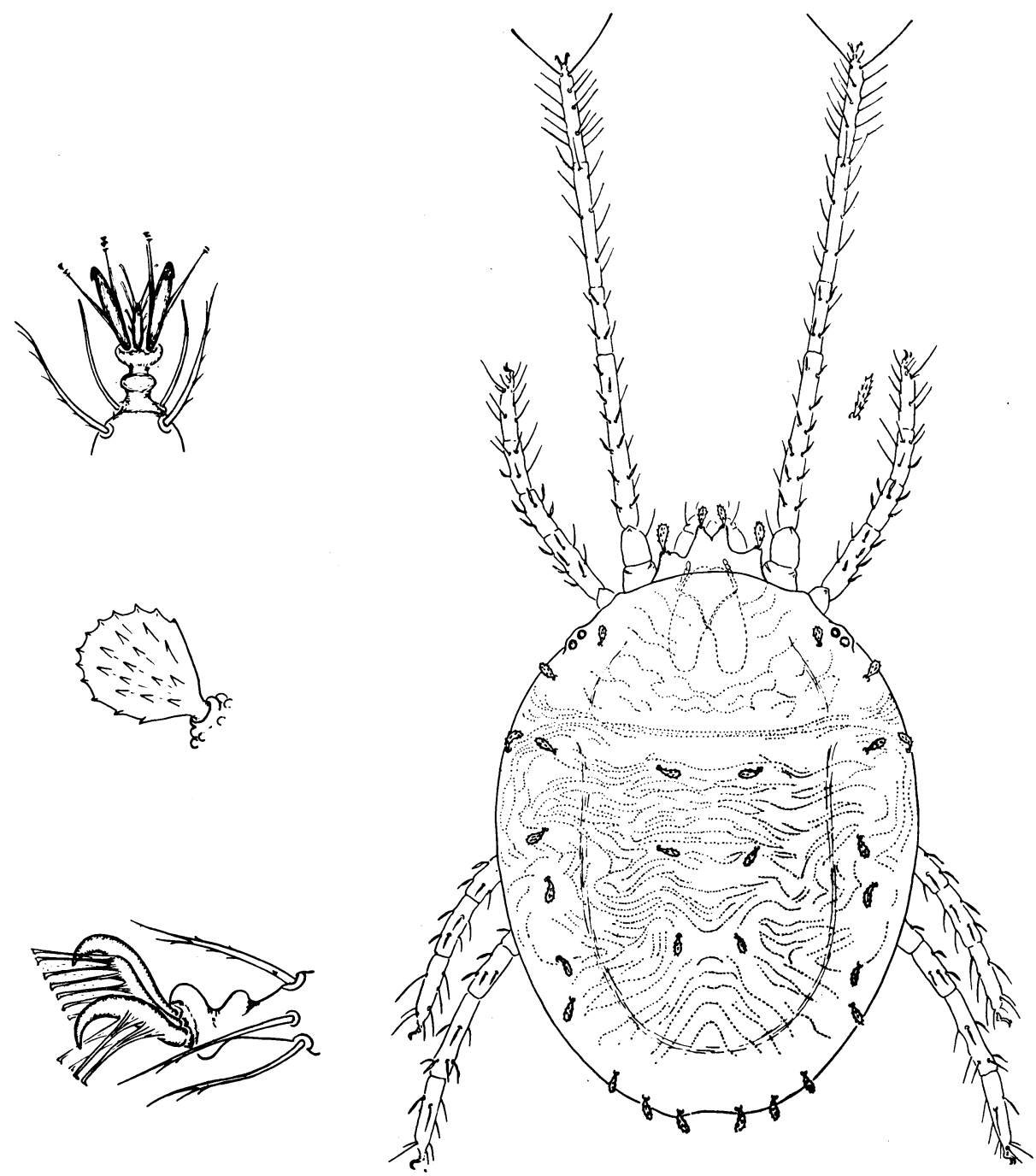

Plate 1. Bryobia praetiosa: dorsal aspect of female, with enlargement of dorsal aspect of appendages of tarsus II, a dorsal seta of the body, and lateral aspect of appendages of tarsus IV. 


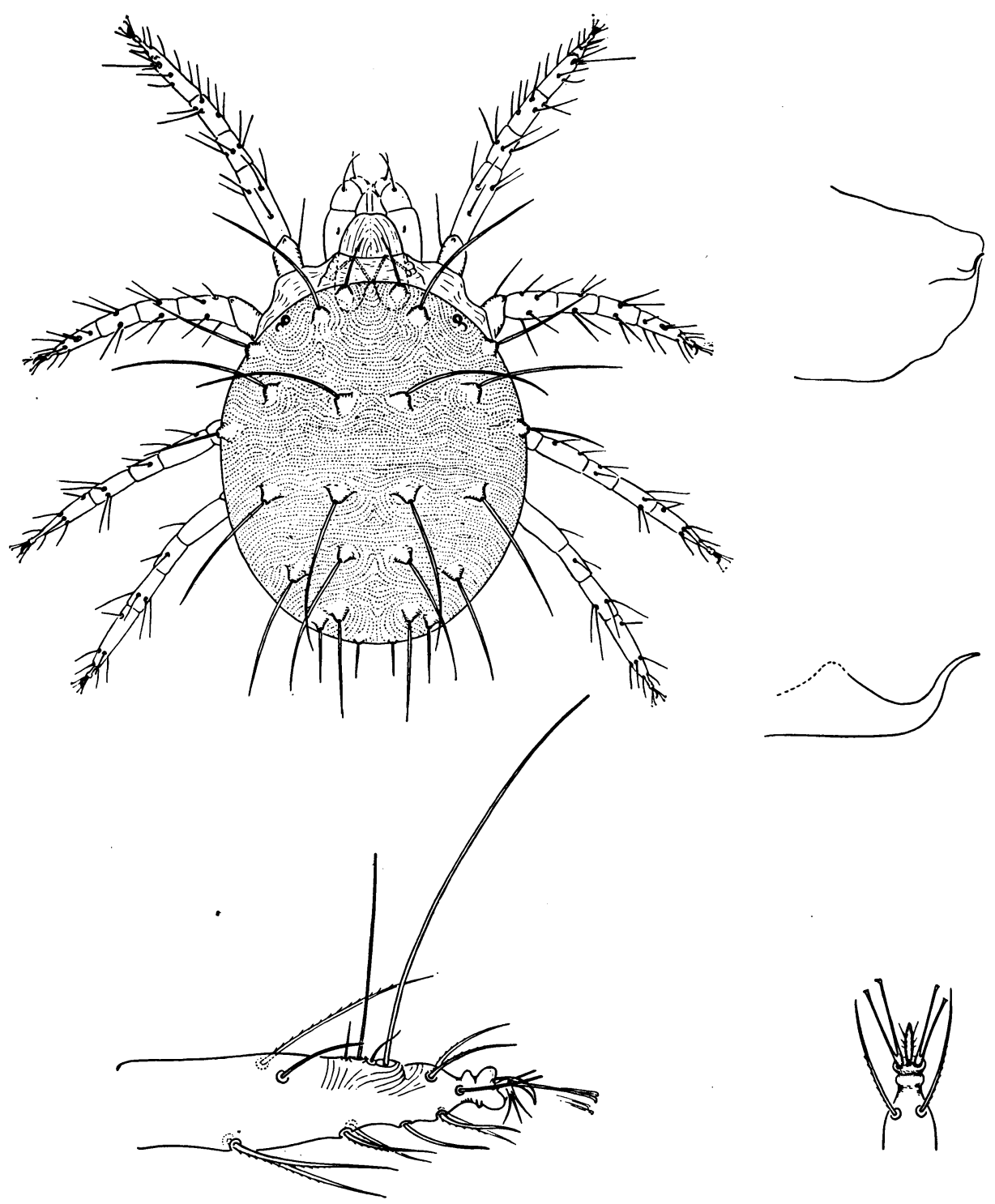

Plate 2. Metatetranychus ulmi: dorsal aspect of female, with enlargements of aedeagus, tarsus I, and dorsal aspect of appendages of tarsus. 

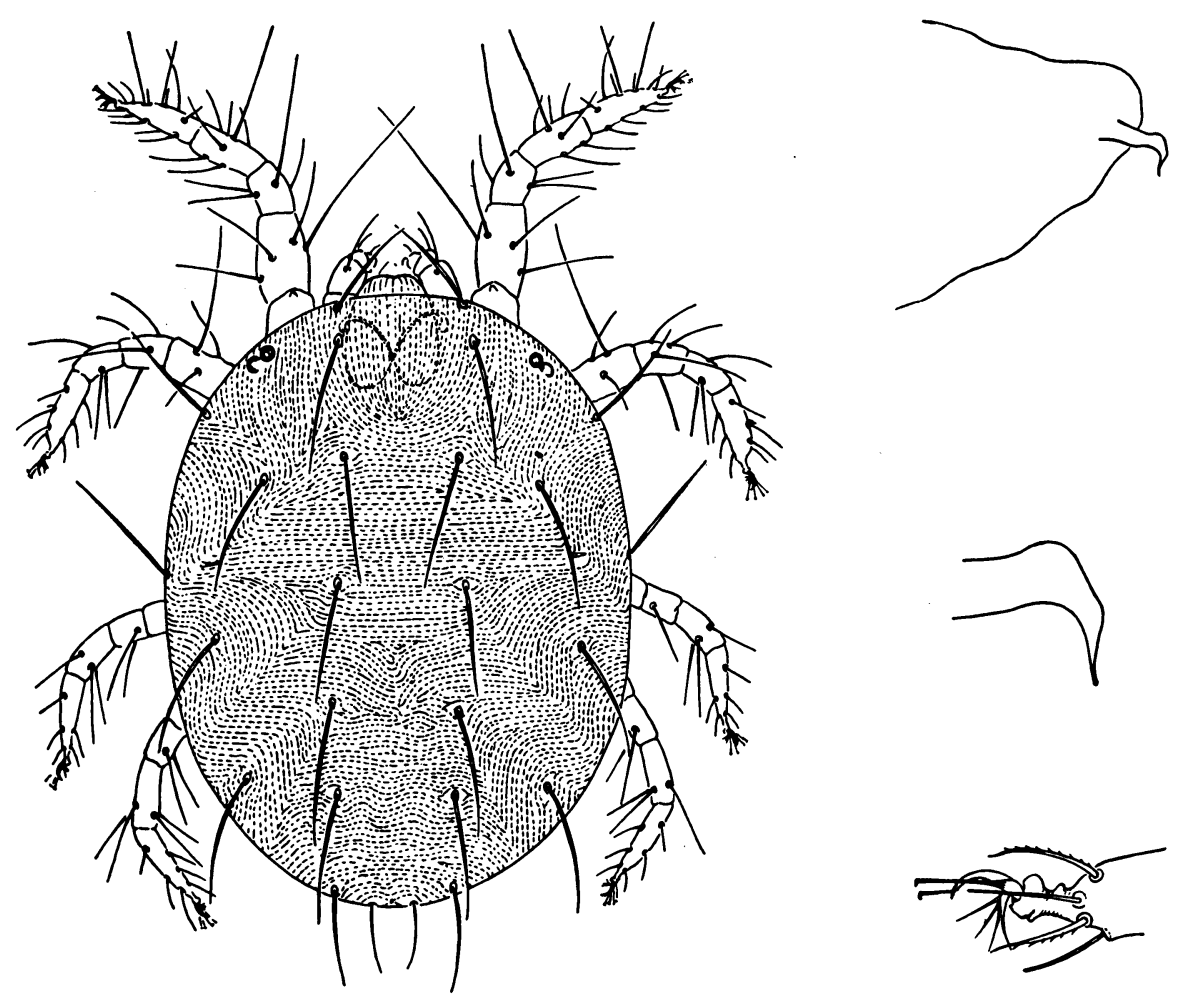

Plate 3. Paratetranychus newcomeri: dorsal aspect of female, with enlargements of aedeagus and lateral aspect of appendages of tarsus II. 


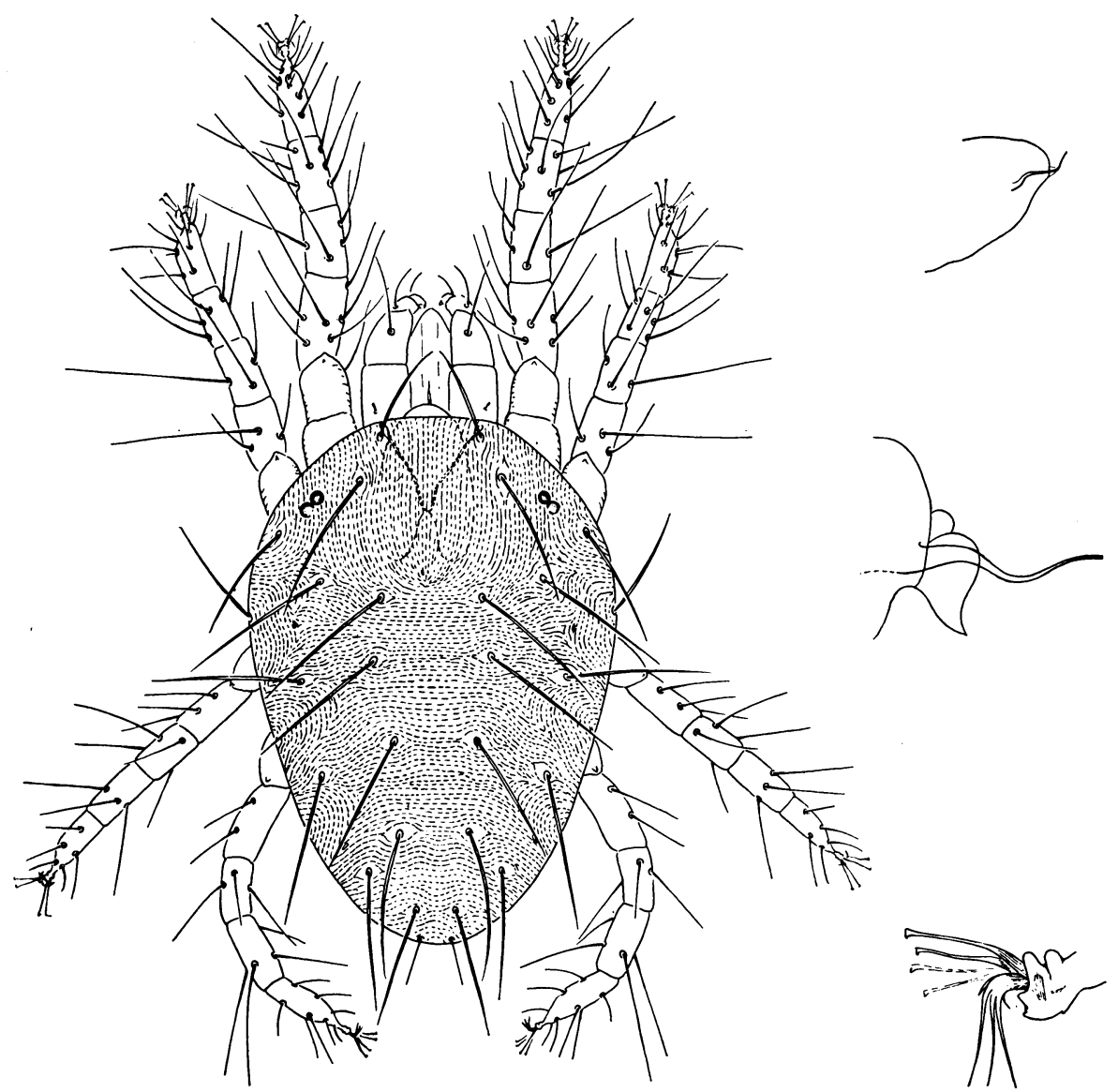

Plate 4. Eotetranychus carpini borealis: dorsal aspect of female, with enlargements of aedeagus; Eotetranychus uncatus : lateral aspect of tarsal appendages. 

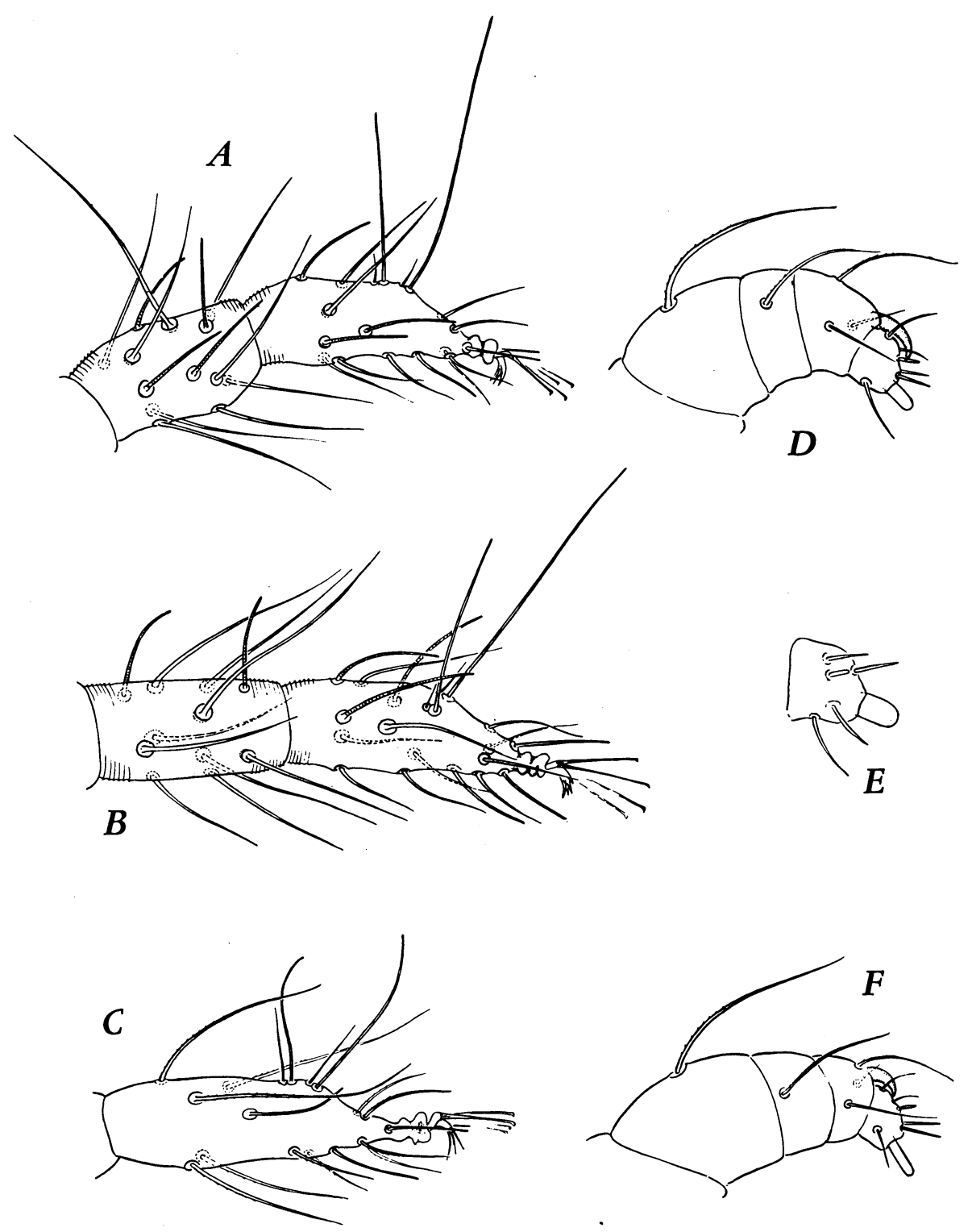

Plate 5. Tibia and tarsus I of male of (A) Eotetranychus carpini borealis, (B) E. uncatus; $(C)$ tarsus I of female of Eotetranychus willamettei; palpus of female of $(D)$ Eotetranychus carpini borealis, $(E)$ E. uncatus, and $(F)$ E. willamettei. 

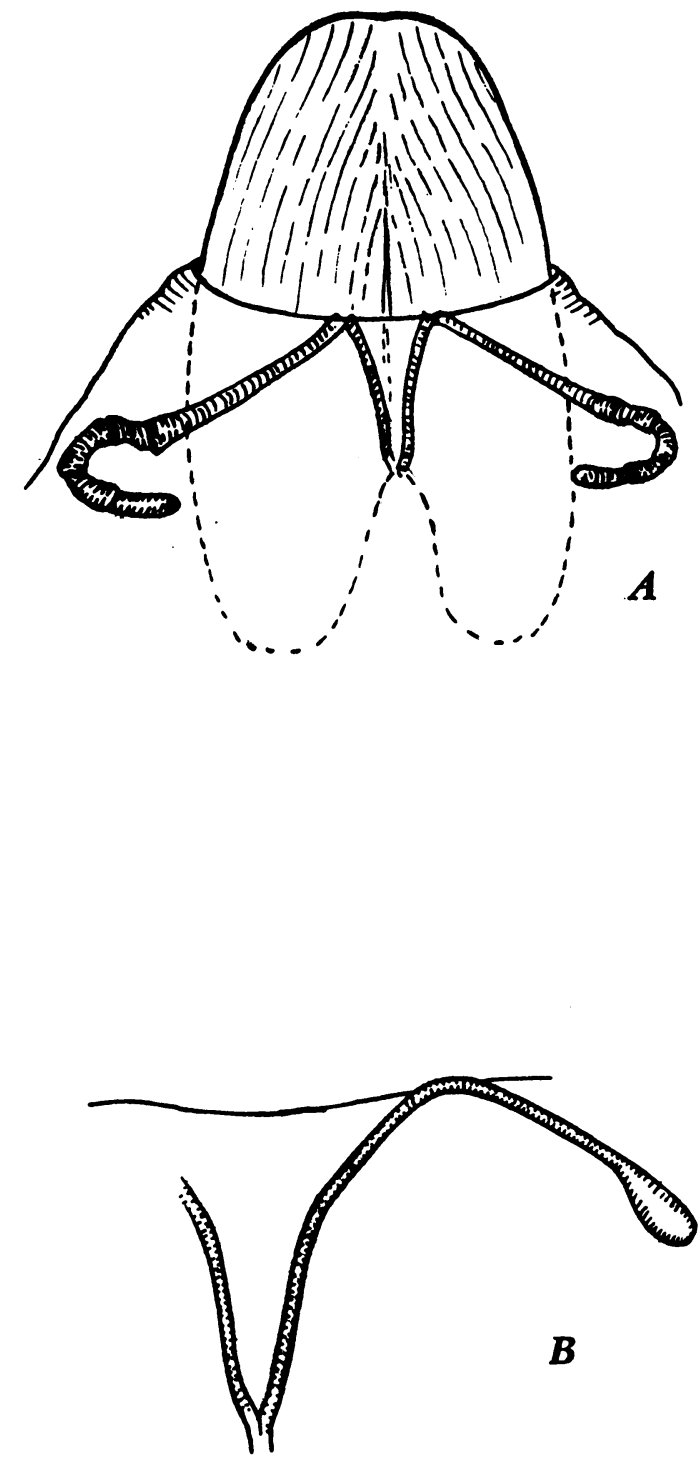

Plate 6. Peritremes of (A) Eotetranychus uncatus and (B) E. carpini borealis. 


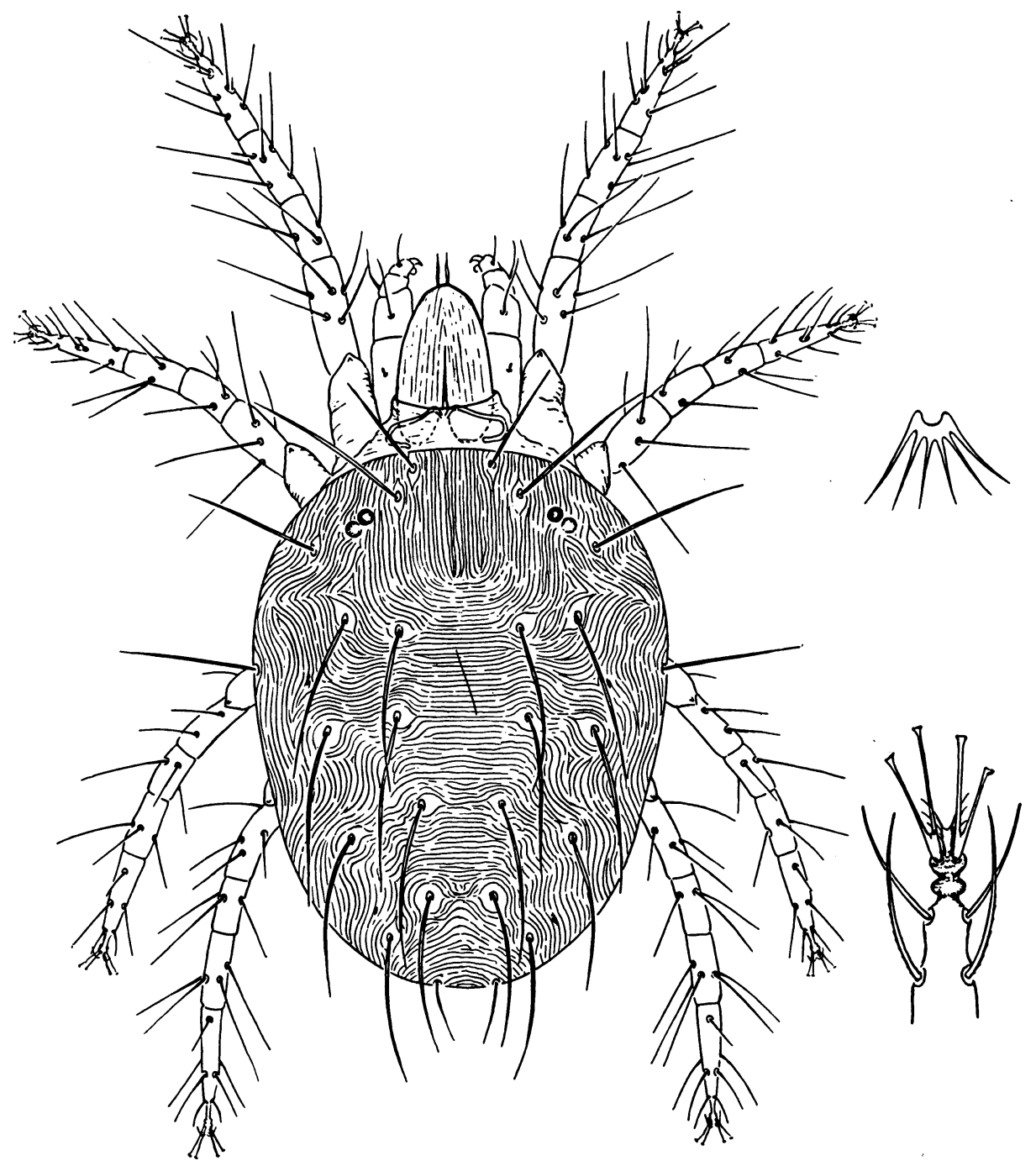

Plate 7. Tetranychus pacificus: dorsal aspect of overwintering female, with enlargement of ventral aspect of empodium and dorsal aspect of tarsal appendages. 

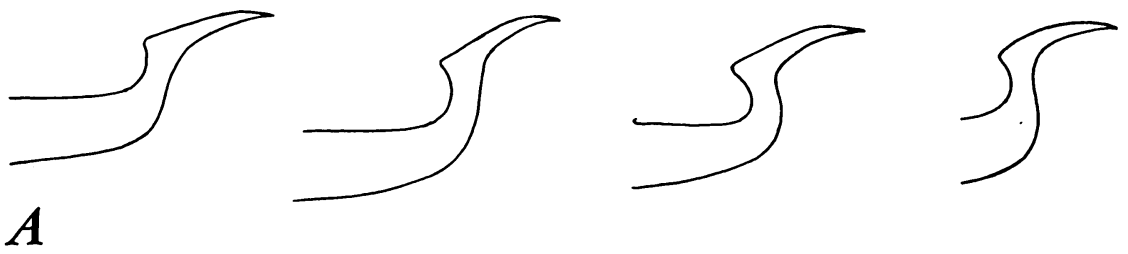

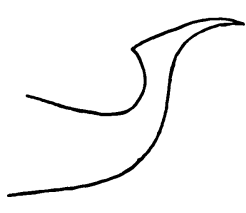

B

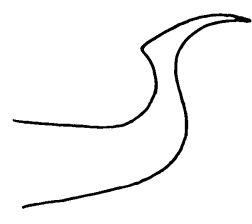

C

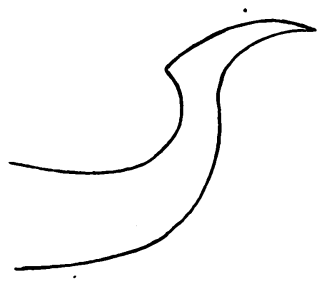

D

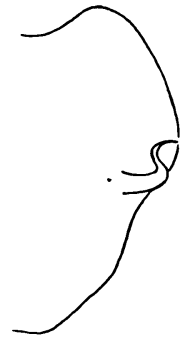

E

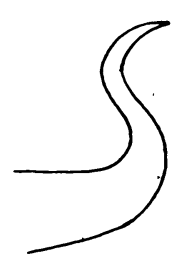

F

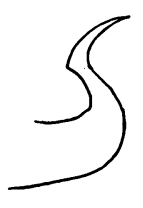

G

Plate 8. Aedeagus of Tetranychus pacificus: $(A)$ Porterville, California, on umbrella tree, (B) Prosser, Washington, on blackberry, $(C)$ Oak Glen, California, on apple, $(D)$ Camp Nelson, California, on mountain mahogany; aedeagus of Tetranychus mcdanieli: ( $E$ ) Fargo, North Dakota, on bramble; $(F)$ Oak Glen, California, on apple, and $(G)$ Hollister, California, on prune. (Drawings are not all to same scale.) 


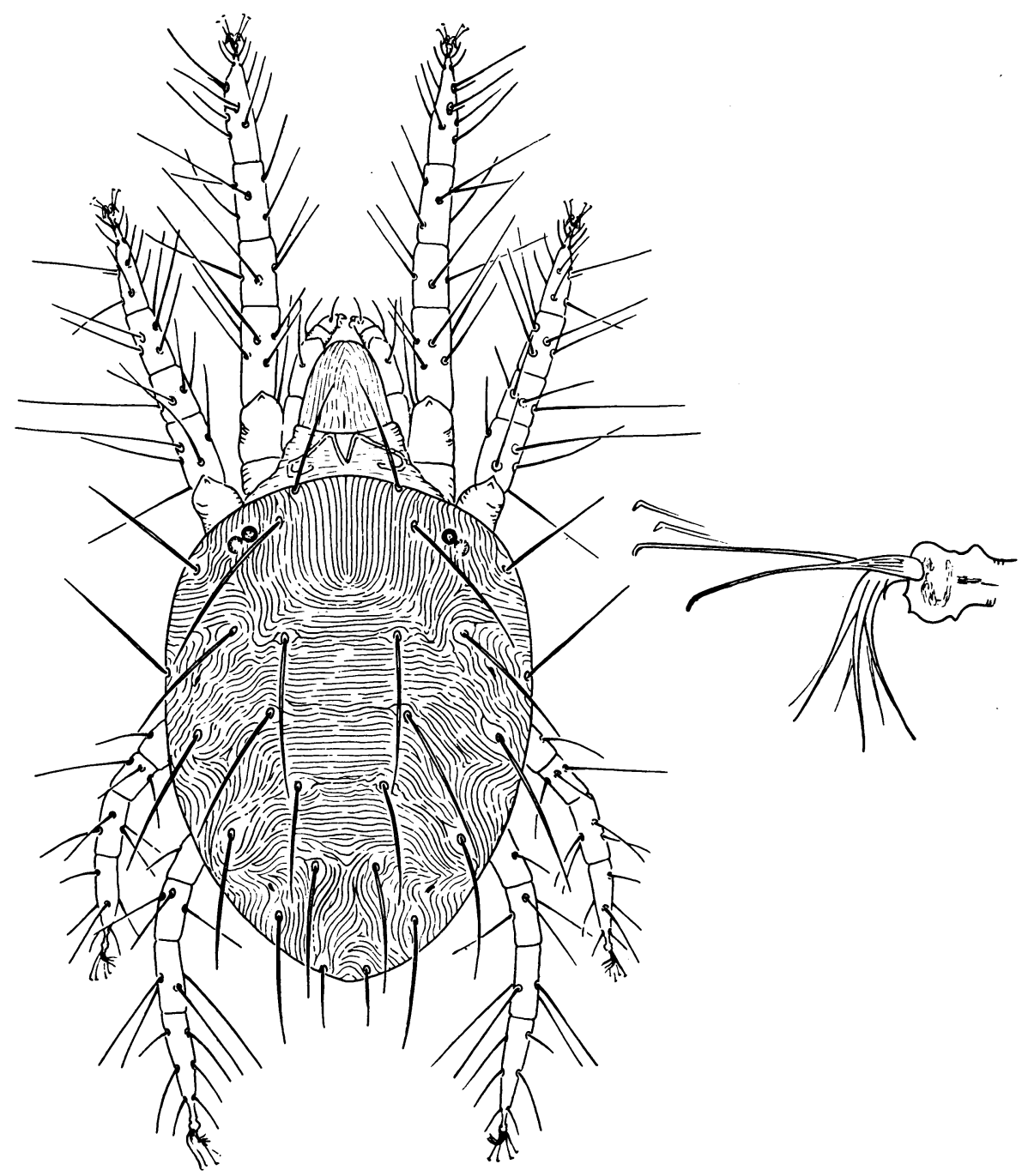

Plate 9. Tetranychus schoenei: dorsal aspect of female, with enlargement of tarsal appendages. 

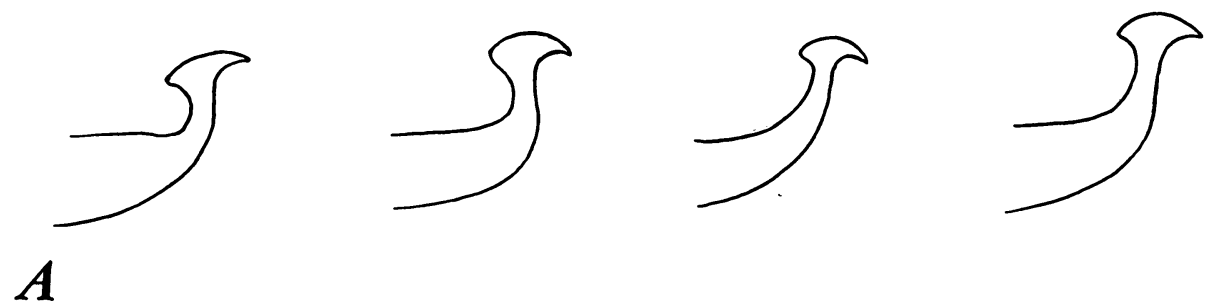

$A$
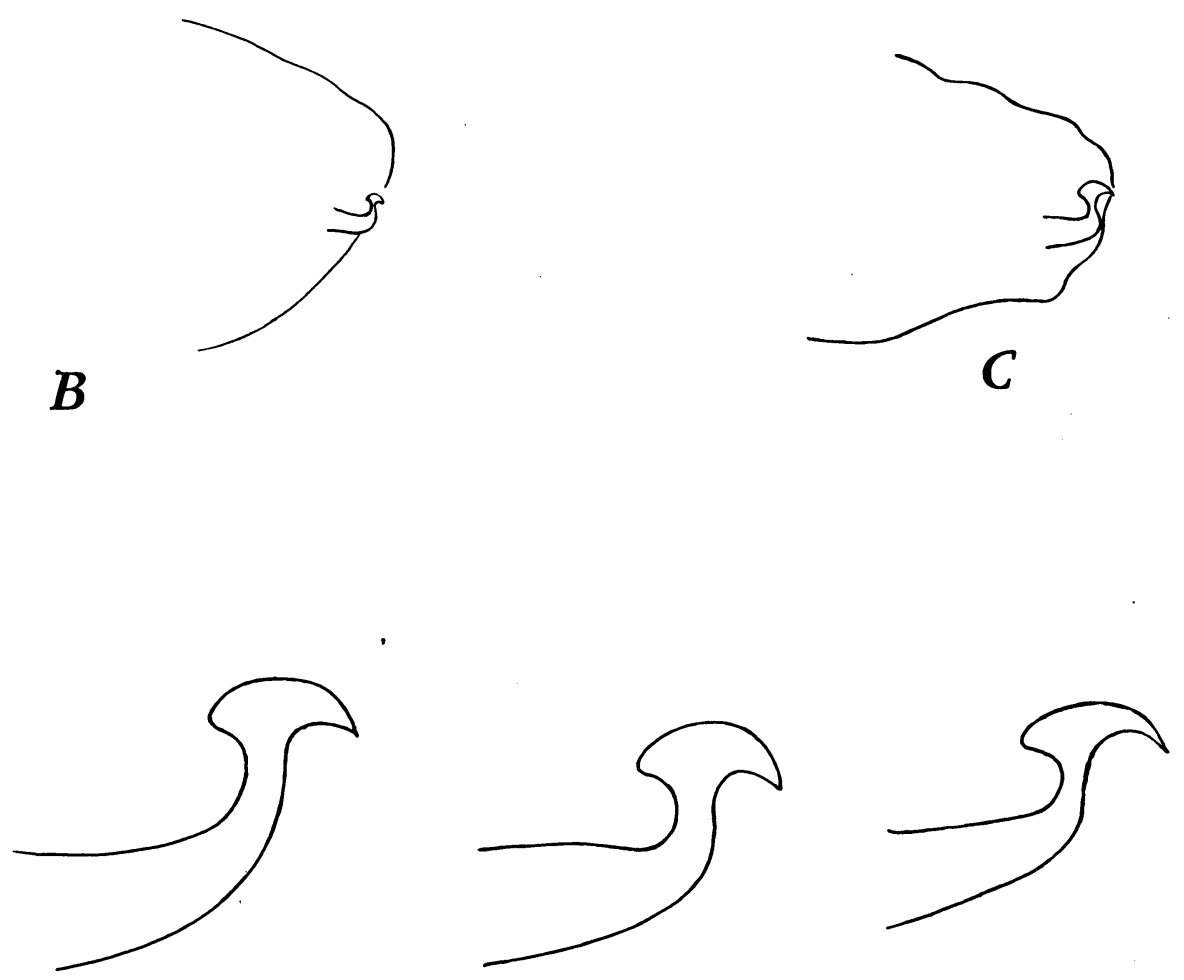

\section{D}

Plate 10. Aedeagus of $(A, B)$ Tetranychus canadensis and $(C, D) T$. schoenei. (The entire cauda $-B$ and $C$-are drawn to the same scale.) 

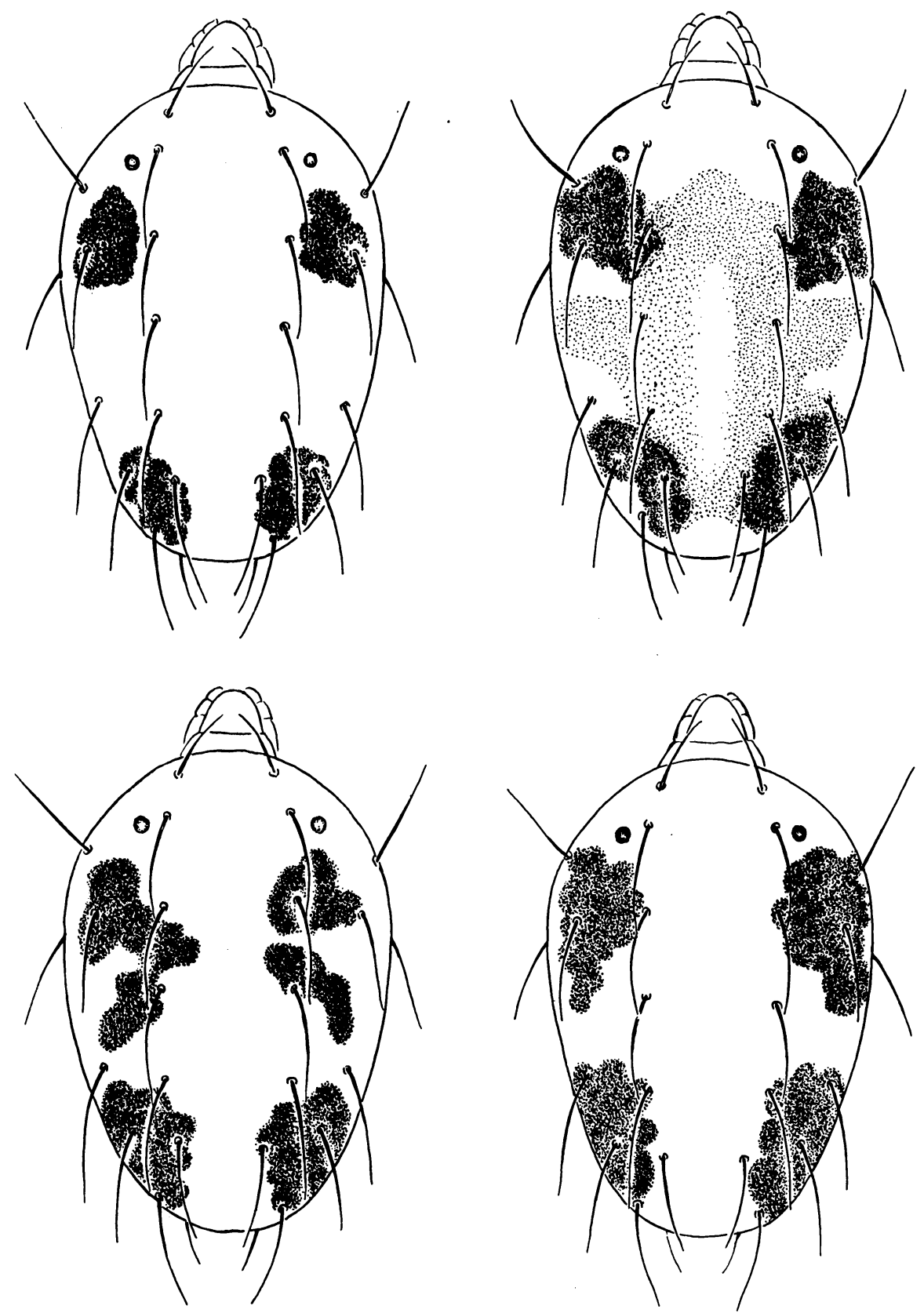

Plate 11. Tetranychus canadensis: dorsal aspect of live females showing certain variations in dark pigment within the body. 


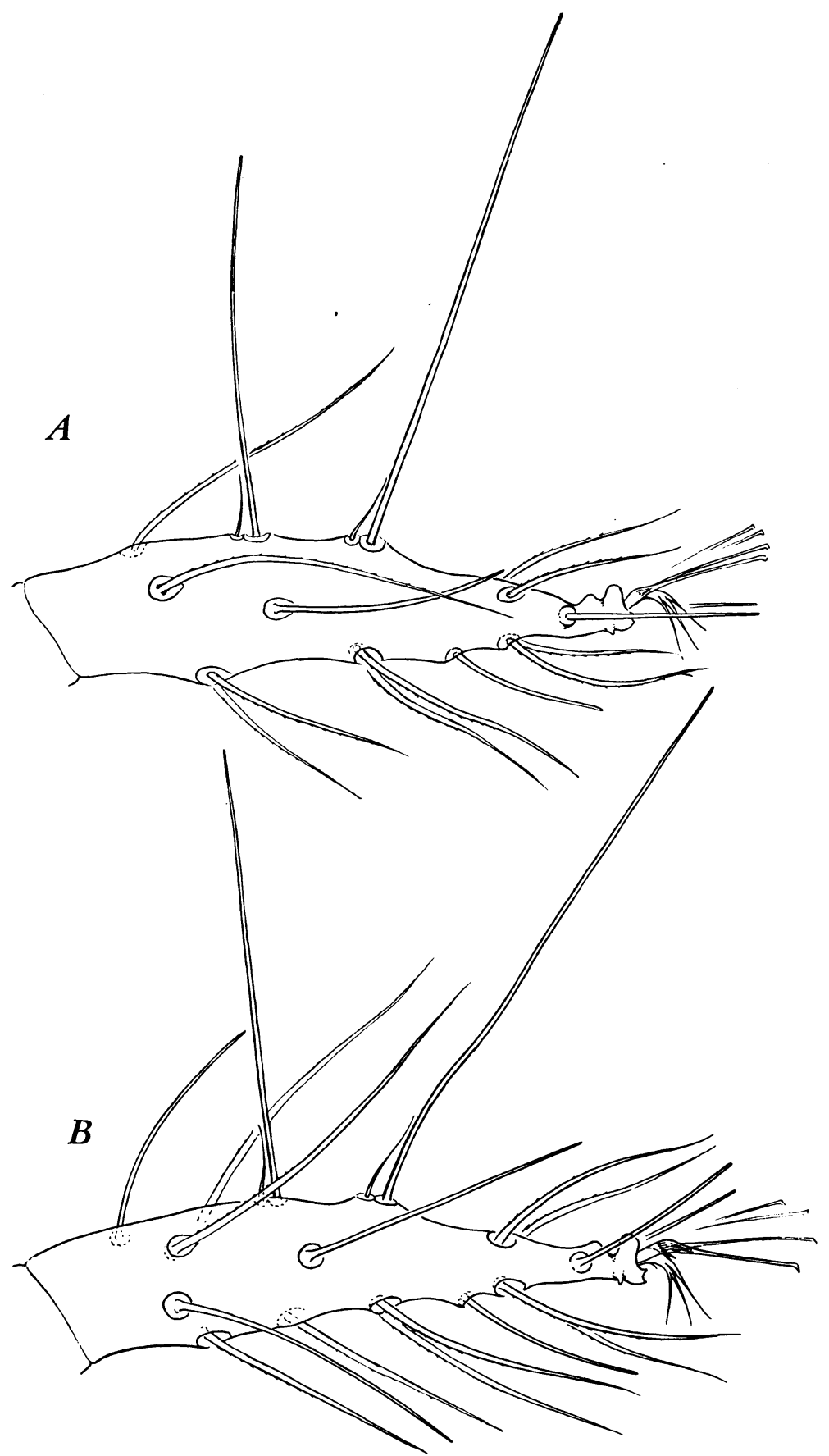

Plate 12. Tetranychus bimaculatus: Tarsus I of female showing (A) typical bimaculatus, and $(B)$ "multisetis" type of chaetotaxy. 


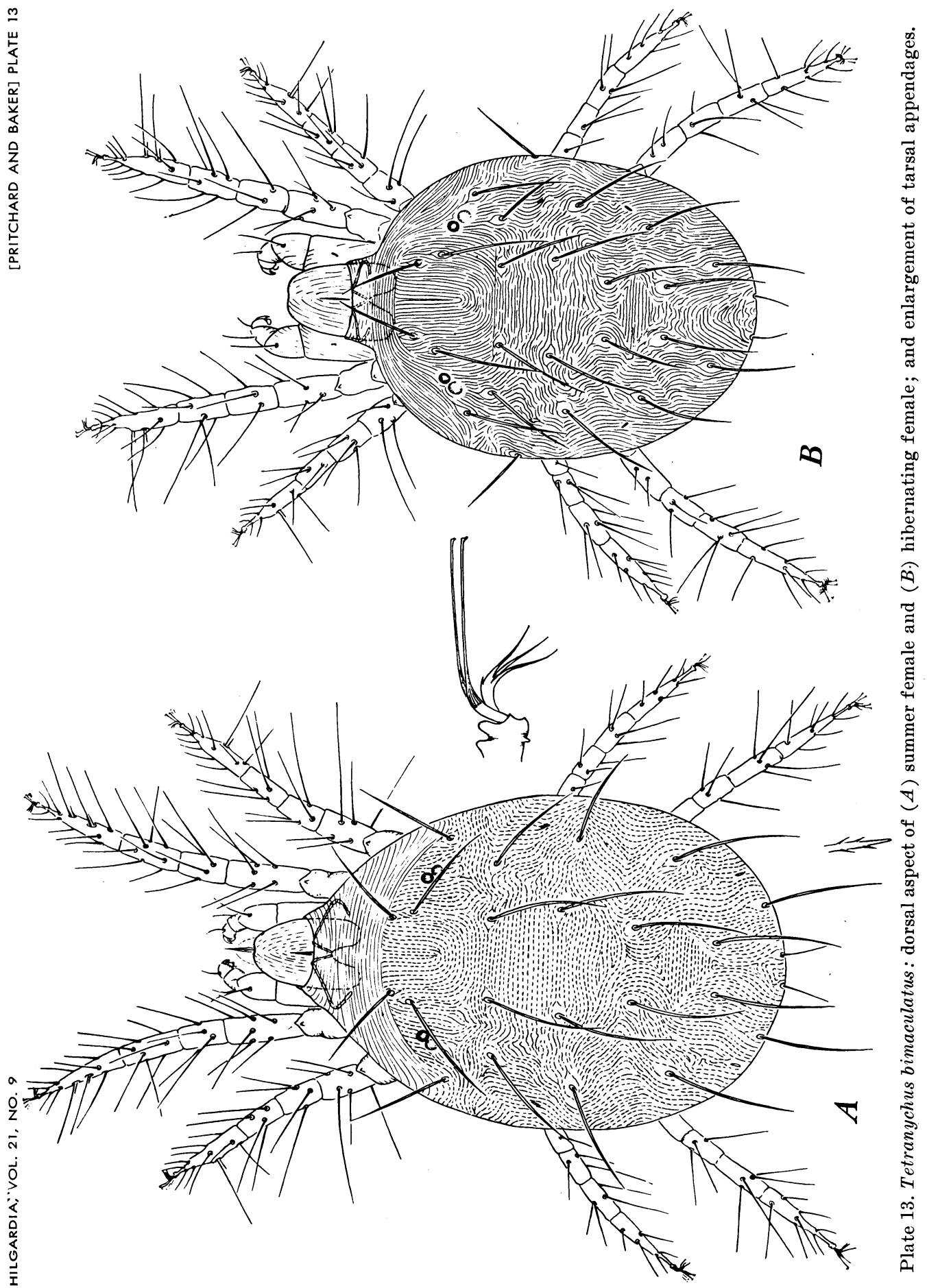


HILGARDIA, VOL. 21, NO. 9
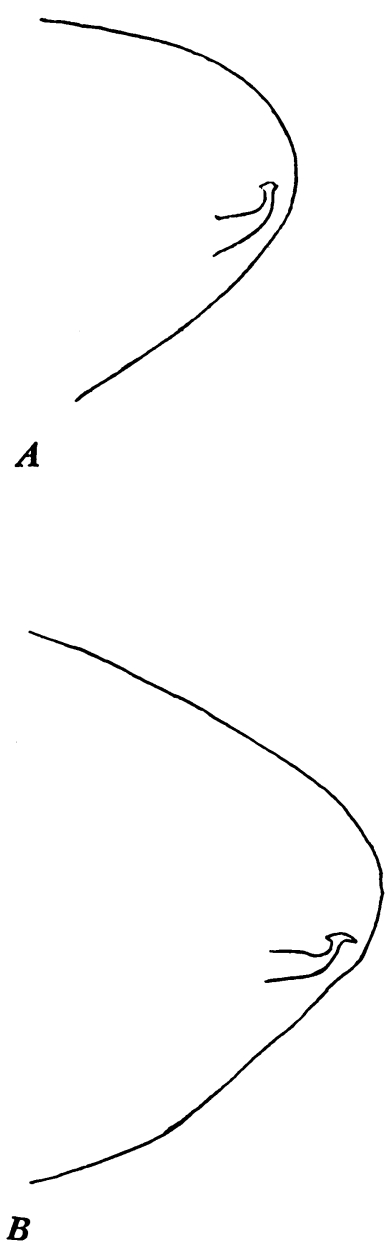

Plate 14. Aedeagus of (A) Tetranychus bimaculatus and (B) T. atlanticus.
[PRITCHARD AND BAKER] PLATE 14
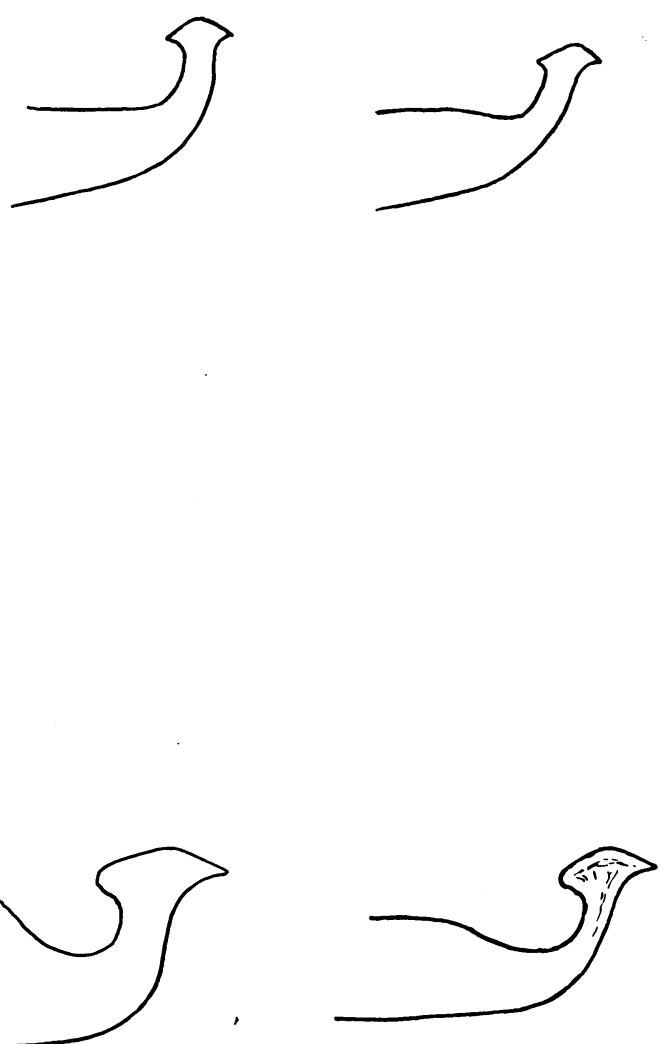


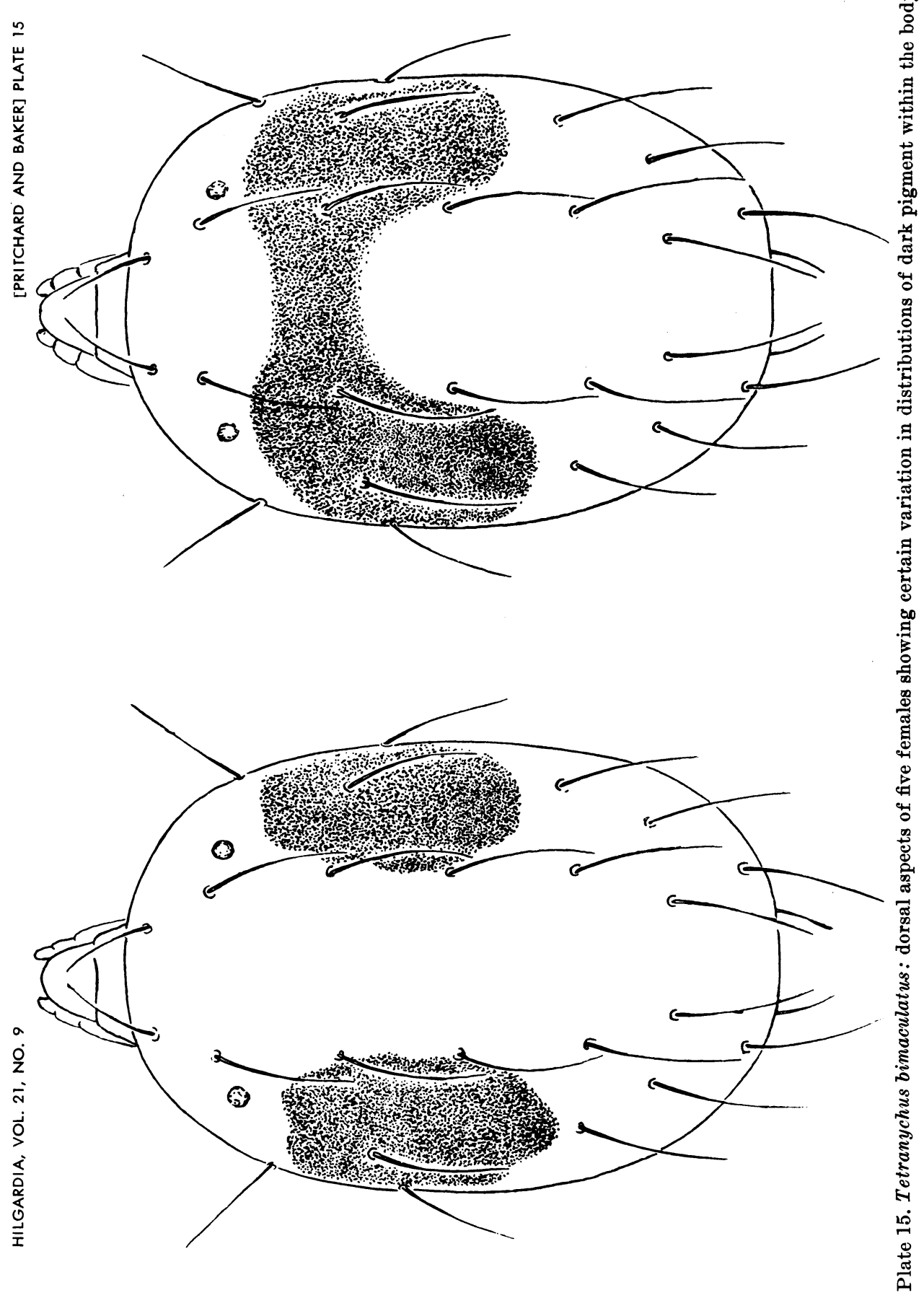



The journal Hilgardia is published at irregular intervals, in volumes of about 600 pages. The number of issues per volume varies.

Subscriptions are not sold. The periodical is sent as published only to libraries, or to institutions in foreign countries having publications to offer in exchange.

You may obtain a single copy of any issue free, as long as the supply lasts; please request by volume and issue number from:

Publications Office

College of Agriculture

Berkeley 4, California

The limit to nonresidents of California is 10 separate issues on a single order. A list of the issues still available will be sent on request. 